\title{
Obras lexicográficas y textos medievales: utilidad de los diccionarios para los historiadores de la Edad Media hispánica
}

\section{Lexicographical Studies and Medieval Texts: Dictionaries Useful for Historians of the Hispanic Middle Ages}

\author{
Elena BAJO PÉREZ \\ Universidad de Salamanca \\ ojabanel@usal.es
}

\section{RESUMEN}

El artículo presenta y describe las principales obras lexicógraficas útiles para comprender el léxico de los textos medievales hispánicos. Ofrece ejemplos concretos de diferentes tipos de búsqueda lexicográfica, pero defiende la idea de que, debido al carácter inconcluso de importantes diccionarios, cada caso debe plantearse como un itinerario singular de búsqueda. Todas las obras que se mencionan en el artículo pueden ayudar en la investigación histórica sobre la Edad Media, pero hoy por hoy dos tesoros (diccionarios de diccionarios), dos diccionarios y dos ficheros en red constituyen las herramientas básicas con las que todo medievalista debería estar familiarizado.

Palabras clave: Diccionarios, Léxico medieval, Búsqueda lexicográfica, Nuevo tesoro lexicográfico de la lengua española, Nuevo tesoro lexicográfico del español, Diccionario histórico de la lengua española, Diccionario del español medieval (DEM), Corpus del nuevo diccionario histórico del español, Tesoro DEMi y ADEM.

\begin{abstract}
The aim of this article is the presentation and description of the main lexicographical works that are instrumental in the understanding of the lexicon of Hispanic medieval texts. It provides particular examples of the different approaches to the lexicographical search, and it also supports the idea that, given the fact that very important dictionaries are unfinished, each case demands a particular search itinerary. All the works mentioned in this article can be helpful in historical research about the Middle Ages, but today two "tesoros" (dictionaries of dictionaries), two dictionaries and two internet archives, should be highlighted as basic tools for every medievalist.
\end{abstract}

Key words: Dictionaries, Medieval Lexicon, Lexicographic Search, Nuevo tesoro lexicográfico de la lengua española, Nuevo tesoro lexicográfico del español, Diccionario histórico de la lengua española, Diccionario del español medieval (DEM), Corpus del nuevo diccionario histórico del español, Tesoro DEMi y ADEM.

Sumario: Introducción. 1. Diccionarios frente a bases de datos. 2. Obras lexicográficas de interés para los medievalistas. 2.1. Obras lexicográficas realizadas en la Edad Media hispánica. 2.2. Diccionarios centrados en el léxico del español medieval. 2.3. Glosarios de obras (y de autores) de la Edad Media. 2.4. Diccionarios generales. 2.5. Diccionarios dialectales. 2.6. Estudios léxicos. 3. La búsqueda léxica. 3.1. Búsqueda inversa (y búsqueda a través de fragmentos). 3.2. Búsqueda semasiológica. 3.3. Búsqueda de nombres propios. 3.4. Búsqueda onomasiologica. 4. Conclusión.

\footnotetext{
${ }^{1}$ Este artículo se inscribe en el Proyecto I+D+I financiado por el Ministerio de Economia y Competitividad "Nuevos métodos para la historia social y política de la Edad Media hispánica: aplicaciones históricas en los corpus textuales informatizados" (HAR2010-17860), dirigido por Ana Isabel Carrasco Manchado (Departamento de Historia Medieval, Facultad de Geografía e Historia, UCM). Todas las obras en línea citadas en el artículo han sido consultadas de enero de 2012 a marzo de 2013.
} 


\section{INTRODUCCIÓN}

Según Bodo MülLER, "más del 40\% del léxico general de los siglos x a XIV se mantiene vivo en la lengua actual. Este es un porcentaje sorprendentemente alto" ${ }^{\text {. No }}$ obstante, eso supone que más de la mitad del léxico medieval resultará desconocido o no del todo familiar a los hablantes actuales. Es bien sabido que la historia de las palabras que se refieren a actividades y objetos concretos no puede establecerse sin conocer la historia de esas actividades y objetos; del mismo modo, apostilla Franz LEBSANFt, la comprensión del léxico intelectual de la Edad Media exige el conocimiento de la filosofía, de la teología y de la medicina de ese período ${ }^{3}$. En último término, las obras lexicográficas que se ocupan del léxico medieval deben servir para salvar la considerable distancia que nos separa de la realidad semiológica medieval.

\section{DICCIONARIOS FRENTE A BASES DE DATOS}

En una época como la actual, caracterizada por la aparición y proliferación de bases de datos, casi siempre disponibles en línea, cabe preguntarse si recurrir a los diccionarios no está condenado a periclitar. Sin duda, los corpus textuales o bases de datos que registran obras completas hacen posible una aproximación rápida y panorámica a la realidad léxica de los textos que incorporan, y el español dispone ya desde hace algunos años de corpus verdaderamente relevantes ${ }^{4}$. Ahora bien, las bases de datos facilitan mucha información, pero de naturaleza muy diferente a la que encontramos en los diccionarios. Podemos recurrir a bases de datos como el CORDE, de la Real Academia Española (<www.rae.es $>$ ) o el CoRpus DEL ESPAÑol de DAVIES, Mark $(<$ www.corpusdelespanol.org $>$ ), para constatar la existencia y documentación de formas concretas del léxico de la Edad Media ${ }^{5}$, para localizarlas con precisión en los textos correspondientes, e incluso, como veremos, para ayudar en la reconstrucción de formas incompletas. Las bases de datos permiten realizar búsquedas con comodines y con operadores lógicos, facilitan concordancias y diversos tipos de recuentos y porcentajes estadísticos, pero no suelen organizarse teniendo en cuenta el significado de las formas documentadas ni su comportamiento gramatical. Por el contrario, los diccionarios se centran en el significado, y cuando - como en el caso del Diccionario Histórico (DH) o del Diccionario del español medieval (DEM) - son diccionarios de citas, arrancan de un planteamiento esencialmente filológico, y, por lo tanto, en ellos leer e interpretar los textos constituye la tarea fundamental. Los diccionarios lematizan las formas, organizan los materiales conforme a su funcionamiento gramatical y

${ }^{2}$ Müller, Bodo: “Aspectos del léxico medieval”, en LüdtKe, Jens y Schmitt, Christian (eds.), Historia del léxico español. Enfoques y aplicaciones, Madrid/Frankfurt am Main, 2004, pp. 61-71.

${ }^{3}$ Lebsanft, Franz: "Historia de las ideas, historia de las palabras, antropología lingüística. Imaginación y fantasía en las Siete Partidas y otros textos medievales españoles", en LÜDTKE, Jens y SCHMitT, Christian (eds.), Historia del léxico español. Enfoques y aplicaciones, Madrid/Frankfurt am Main, 2004, pp. 39-60.

${ }^{4}$ Para una revisión actualizada de los distintos corpus y de su utilidad en los estudios históricos, véase Carrasco Manchado, Ana Isabel: "Nuevas herramientas para la historia de la Edad Media hispánica: los corpus textuales informatizados", En la España Medieval, 34, 2011, pp. 343-372.

${ }^{5}$ Para esto hasta se podría recurrir a buscadores generales de Internet, como Google. 
semántico y si además se conciben como diccionarios exhaustivos, aspiran a inventariar el léxico total de una lengua bien en una determinada época (caso del DEM), bien a lo largo del tiempo (caso del $D H$ ).

En resumen, un corpus y una obra lexicográfica se distinguen de forma radical en la manera de proceder frente a las unidades léxicas; en un corpus textual, la calidad va unida a la cantidad: hay que registrar muchos textos, registrarlos completos y de forma fiable, facilitar concordancias de línea y de párrafo, permitir consultas complejas, con filtros por años, por autores, por obras, etc. Lo más importante en un corpus es poder trabajar rápida y comparativamente con una ingente cantidad de datos bien localizados. Por el contrario, lo fundamental en un diccionario (aunque hay diccionarios de muy distintos tipos) es el tratamiento del significado: qué se define, cómo, conforme a qué criterio se estructuran y ordenan los distintos significados. Se ha repetido hasta la saciedad, pero con razón, que lo esencial y medular en un diccionario es la definición; todas las restantes informaciones que puede ofrecer un diccionario importan, por supuesto, pero la definición constituye siempre su piedra de toque.

Puesto que existen muchos y variados diccionarios, seguiremos el siguiente orden en el apartado 2: 2a) obras lexicográficas realizadas en la Edad Media, 2b) obras centradas en la recopilación del léxico medieval (diccionarios, vocabularios y glosarios), 2c) glosarios de obras (y de autores) de la Edad Media, 2d) diccionarios generales de interés para medievalistas, 2e) diccionarios dialectales, $2 \mathrm{f}$ ) estudios sobre léxico medieval.

\section{OBRAS LEXICOGRÁFICAS DE INTERÉS PARA LOS MEDIEVALISTAS}

\subsection{OBRAS LEXICOGRÁFICAS REALIZADAS EN LA EDAD MEDIA HISPÁNICA}

¿Hasta qué punto puede resultarle útil a un historiador consultar las obras lexicográficas medievales españolas? Suponiendo que se interesara por los rasgos sociolingüísticos de un texto medieval, sí le convendría atenerse a los diccionarios contemporáneos. Ahora bien,

A la hora de abordar el estudio diastrático de los textos medievales nos vamos a encontrar con bastantes limitaciones. La lexicografía de la Edad Media se limitó, como sabemos, a las glosas marginales o interlineales que los lectores de textos latinos pusieron en romance en el manuscrito para hacerlo comprensible. En las glosas se puede deducir muy difícilmente la extracción social de las palabras romances, esto es, el nivel de lengua al que pertenecen, a no ser que éste se diga explícitamente o aparezca un polimorfismo que sea esclarecedor. Deberíamos recurrir ante la escasez de datos a otros textos romances - del mismo dialecto, claro está- y confrontar variantes ${ }^{6}$.

\footnotetext{
${ }^{6}$ Medina Morales, Francisca: "La importancia de los diccionarios en el análisis sociolingüístico histórico", en Ruhstaller, Stefan y Prado Aragonés, Josefina (eds.), Tendencias en la investigación lexicográfica del español, Huelva, Universidad, 2000, pp. 497-504. Véase también, Ariza Viguera, Manuel: "Diccionarios 
No obstante, contamos también con glosarios independientes de textos concretos: los bilingües latino-españoles se pueden aprovechar en toda su riqueza, gracias a la magistral y clarificadora edición de Américo CASTRo (v. infra [5a, 5b, 5c]). En cuanto al Vocabulario castellano del siglo $X V$ (v. infra [6]), brinda numerosas opiniones sobre el uso de los vocablos: propio o desviado, anticuado, neológico, popular, etc. Pero, sobre todo y ante todo, a los medievalistas podría convenirles tener en cuenta las múltiples definiciones dispersas a lo largo de la obra de Alfonso $\mathrm{X}$, las cuales no configuran una obra lexicográfica en sentido estricto, por lo que hablaremos de su recolección y edición en el apartado siguiente.

Así pues, sin salirnos del ámbito de la lexicografía española, conviene recordar que podemos contar con las siguientes obras ${ }^{7}$ :

[1] Glosario Turza (año 960): GArcía Turza, Claudio y García Turza, Francisco Javier, Fuentes españolas altomedievales. El códice 46 de la Real Academia de la Historia, primer diccionario enciclopédico de la Península Ibérica, Madrid, Caja Rioja/RAH, 1997. "El glosario abarca más de 25.000 artículos, con más de 100.000 acepciones". Está escrito en latín, "pero en un latín adulterado, que contiene ya elementos puramente romanceados".

[2] Glosas Emilianenses (mediados del s. X, o s. XI):

a) edición y estudio de García Larragueta, Santos, Logroño, Comunidad de La Rioja/IER, 1984,

b) edición de Wolf, J., versión española de Ruhstaller, S., Sevilla, Universidad, 1996.

Los materiales léxicos de estas glosas pueden consultarse con mucha mayor facilidad en el Léxico Hispánico Primitivo (v. infra [20]).

[3] Glosas Silenses ( $2^{\mathrm{a}}$ mitad del s. x o más tarde): edición crítica y facsímil con estudios de Hernández Alonso, C., Fradejas Lebrero, J., Martínez Díez, G. y Ruiz Asencio, J. M., Burgos, 1993.

También los materiales léxicos de estas glosas pueden consultarse con mucha mayor facilidad en el Léxico Hispánico Primitivo (v. infra [20]).

[4] Glosario mozárabe (h. 1100), probablemente de Abu-1-Hayr al-Isbili, como defiende AL-Arabi, Muhammad en sus dos ediciones (Rabat, 1990 y Beirut) y admiten ya Bustamante, Joaquín, Tilmatine, Mohamed y Corriente, Federico en su edición crítica (Madrid, csic, 2004-2010). Asín PALAcios, Miguel lo había editado parcialmente bajo otro título: Glosario de voces romances registradas por un botánico anónimo hispano-musulmán, Madrid, CsIC, Imprenta de la Viuda

históricos del español y reflejo social del cambio léxico", en Prado, Josefina y Galloso, M. ${ }^{a}$ Victoria (eds.), Diccionario, léxico y cultura, Huelva, Universidad, 2004, pp. 35-44.

7 Para una descripción pormenorizada de las diferencias entre glosarios, diccionarios, repertorios (tablas, concordancias, distinctiones, etc.) en ese período, véase WeIJERs, Olga: Dictionnaires et répertoires au moyen âge, Brepols, Turnhout Belgique, 1991. Para los antecedentes en la antigüedad grecolatina y en la Edad Media, en griego, latín, árabe y hebreo, véase BAJo PÉrez, Elena, Diccionarios. Introducción a la historia de la lexicografía del español, Gijón, TREA, 200, pp. 55-62. Para la lexicografía del español en la Edad Media, véase ibídem, 62-76, y Freifrau von Gemmingen, Barbara: "Los inicios de la lexicografía española", en Medina Guerra, Antonia M. (coord.), Lexicografia española, Barcelona, Ariel, 2003, pp. 151-174. 
de Estanislao Maestre, 1943. Es obra importante para los nombres botánicos en los distintos romances que se hablaban en la península en aquel momento. Además, el tercer volumen de la edición crítica mencionada "contiene unos índices exhaustivos, para que la obra sea una herramienta eficaz para los botánicos, los lexicógrafos y los historiadores".

[5a, 5b, 5c] Glosarios latino-españoles de Palacio (P), de Toledo (T) y del Escorial (E) (todos de fines del s. XIV o de principios del s. XV): fueron editados conjuntamente por CASTRO, Américo, bajo el título Glosarios latino-españoles de la Edad Media, Madrid, CSIC, 1991. Consta de estudio preliminar, reproducción de los tres glosarios y del apéndice, vocabulario general (reunión por orden alfabético del material de los tres glosarios, con explicación de las voces latinas y de sus correspondientes glosas), índice de voces españolas, comentario al apéndice del Glosario del Escorial, adiciones y enmiendas. En el Nuevo Tesoro Lexicográfico del español (NTLE) (v. infra [31]), el rastreo y registro de los materiales proporcionados por los diccionarios antiguos arranca precisamente de estos glosarios, por lo cual también desde esta recopilación se puede acceder a la información que contienen.

[5b2] Del Glosario de Toledo existe otra edición a cargo de WAID, Gloria Castresana: Glosario latino-romance del siglo XV, Nueva York, Dissertation Abstracts International, 1978. Editado tambien por la editorial Beramar en 1986.

[6] Vocablos difíciles del castellano o Vocabulario castellano del siglo XV o Vocablos castellanos. Es una obra anónima, que contiene 152 entradas en las que abunda la información enciclopédica. El único bloque tratado sistemáticamente lo constituyen las voces referidas a la caballería (unas treinta). V. Huarte MorTON, Fernando: "Un vocabulario castellano del siglo Xv", Revista de Filología Española, Xxxv (1951), 310-340. Bien inventariados en el Apéndice, bien comentados a lo largo del artículo, Huarte menciona las 152 voces que figuran en este vocabulario. No ha sido incluido en el Nuevo Tesoro Lexicográfico de la lengua española (NTLLE), pero sí en el NTLE (v. infra [31]), "aunque prescindiendo de parte del texto por considerarlo innecesario para los fines de nuestro Nuevo Tesoro" (p. XLII del apartado Fuentes).

[7a] Universal vocabulario en latín y en romance, de Alfonso (FERNÁNDEZ) DE PALENCIA: Sevilla, Paulus de Colonia, 1490. Reproducción facsímil: Madrid, Asociación de Academias de la Lengua, 1967, 2 volúmenes. No ha sido recogido en el NTLLE, pero sí en el NTLE (v. infra [31]), aun reconociendo "las enormes dificultades que entraña la incorporación de estos materiales" y "la imposibilidad de mantener un criterio uniforme, entre otras razones por la propia naturaleza de la obra" (p. LII del apartado Fuentes).

[7b] Universal vocabulario de Alfonso de Palencia. Registro de voces españolas internas, de HiLl, J. M., Madrid, Aguirre Torre, 1957. Recopilación utilísima para acercarse a la obra de Alfonso de Palencia de una forma más cómoda; eso sí, prescinde de la mayor parte de los nombres propios y de las explicaciones enciclopédicas. 
[8a] Diccionario latino-español, de NebriJA, Elio Antonio de, Salamanca, s.n., 1492.

[8b] Vocabulario español-latino, Salamanca, de Nebrija, Elio Antonio de, s.n., s.a. [¿1495?]. Ambos tuvieron muchas reediciones sucesivamente ampliadas, tanto en vida de su autor como posteriormente.

Por su importancia capital en la historia de la lexicografía española, existen ediciones facsímiles y centenares de estudios sobre estas dos obras, pero para los historiadores resultará más práctico acceder a sus materiales a través del NTLLE (v. infra [30]), que permite ver página a página del Vocabulario en su primera edición y en la de 1516 (Sevilla, Varela), y a través del NTLE (v. infra [31]), que, para el Diccionario, se basa en la primera edición y, para el Vocabulario, en la primera edición y en la de 1520 (Alcalá de Henares, Arnao).

[9] Vocabulario eclesiástico, de Fernández de Santaella, Rodrigo, Sevilla, Juan Pegnitzer et al., 1499.

Fue concebida para ayudar a entender los textos bíblicos y eclesiásticos en latín, por lo que registra también mucho vocabulario no específicamente eclesiástico; los lemas van en latín y las definiciones en castellano. Sus materiales han sido tenidos en cuenta por el NTLE (v. infra [31]), con la excepción de la información relativa a los nombres propios, que es considerable.

\subsection{DICCIONARIOS CENTRADOS EN EL LÉXICO DEL ESPAÑOL MEDIEVAL}

Por desdicha, pese a los innegables avances que se han producido en los últimos años, mantienen del todo su vigencia las palabras de Gómez Redondo, Fernando ${ }^{8}$ :

Inventariar la totalidad del léxico medieval para presentarlo bajo la forma de diccionario ha resultado siempre un proyecto tan ambicioso que ha parecido rozar la pura utopía. Así, al menos, lo muestran las diversas tentativas que se aplicaron a tal empeño sin terminarlo o sin lograr siquiera una representativa sistematización de los vocablos.

Vamos a describirlos someramente en orden cronológico de aparición.

[10] Cejador y Frauca, Julio: Diccionario medieval castellano, Madrid, 1929. Reimpresiones de 1971, 1990 y 2005 (Madrid: Visor). Recoge las voces encontradas en sus innumerables lecturas junto a las citas correspondientes, pero no siempre define.

${ }^{8}$ Gómez Redondo, Fernando: "Lexicografía medieval: proyectos y realizaciones", Dicenda. Cuadernos de Filología Hispánica, 8 (1989), pp. 231-239. También disponible en línea. 
306

PER-CONTAR. J. ENc., 79: Tanta batalla de puerros, I que no lo sé percontar.

PERCOYO. J. ENC., 195: No hablo en ganado, ni casa o percoyo.

PER-CREER. J. ENC., Bibl. Gall., 2, 893: Que ya te voy percreyendo | segun oyo grandes gritos.

PERCUDIDO, violento. Alex. 1999: las sierpes davan silvos malos e percudidos.

PERCUDIR. S. BADAJ., I, p. 97: Arrojole de pernadas, | que s: le acertara, a osadas | la cholla le percudiera. J. ENC., 23: Mateo, si no rebellas | y te percude cariño, | vamos a ver aquel niño. Id., I I4: Que ya no quiero otra cosa, I ni me percude otro antojo. Luc. FER., 37: Gran suerte nos percudió.

PERCUNDI-O. Posv. de percundi-r, ojeriza. J. ENC., I46: Ningu: percundio les tomo.

PER-CUNDIR. L. FERN., I44: No puedo entender, zagal, I ni percundo | tu enfingir de mayoral. J. Exc., Bibl. Gall., 2, 899: No nos acosan amores, I no nos percunde su fuego?

PER-CUT-IDO. S. BADAJ., I, p. 92 : ¿Quien es aquel percutido, | que viene cucuruzado | como capon señalado? Id., 2, p. 37 : Para esta dun percutido / dejareis el chabacano.

PER-CHAPADO. L. FERN., 88: Quien me vió mas perchapado | y mas ñotado | que se vió en la serranía.

PER-CHUFAR. v. a. Chufar mucho o digase burlar. J. ENcr.v. 92: Esos que sois de ciudad | perchufais huerte de nos. RodR. REI-
NoSA, Gallard., 4, I4I5: ¡O! 1:0 praga Dios, contigo! | fuertes perchufas comigo.

PER-DANOOSO, adj. pastoril. Muy dañoso. J. Encin., 85: Es perdañosa y bellaca.

PERDER, de perdër(e). J. Ruiz, 46I : perdíame de sed.

PERDIBLE. BAENA, p. II 7 Pẹnetre tinieblas del mundo perdible.

PERDIDOSO (clas.), el que pierde. BAENA, p. 325: temo de seer perdydoso en lo que soy ffyador.

PERDIENTE, partic. pres. BERCEO, S. Lor., 59: avie un omne bueno que perdiente el viso.

PERDONANZA, -ÇA, -SA. BAENA, p. 468: perdonansa.

PERDUDO, partic. de perder. BERCEO, Mil., 772 : sennor so perdudo e so desamparado. J. Ruiz, I3IO: por la çibdat andava rradi's e perdudo.

PEREGRIN-AJE. Valer. Max., I, 2: Adonde las damas de Atenas eran idas en peregrinaje. PEREGRINO, PELEGRINO. S. María Eg., 269: lena era de pelegrinos.

$P E R E J I L-A R S E$ adornarse. Corvacho, 2, 4: El diablo aya parte en estas perexiladas.

PER-ENTENDER. J. ENCI. NA, 153: De atordido | no pudi: perentenderlo.

PEREZA, PERESA, de pi $(y)$ rutia(m). J. Ruiz, 45: son en la grand peresa miedo e cobardía.

$P E R E Z-A R$, tener perez-a. L. FERN., I80: No cumpre más perezar.

[11] PotтIER, Bernard: «Lexique Médiéval Hispanique" en Cahiers de linguistique hispanique médiévale, $\mathrm{n}^{\circ} 5$ (1980) A-B, pp. 195-247; $\mathrm{n}^{\circ} 6$ (1981) C, pp. 179-217; no 7 (1982) CH-E, pp. 135-152; no 8 (1983) F-G, pp. 197-209; no 9 (1984) H-J, pp. 177-187; n 12 (1987) L-O, pp. 5-26; n 16 (1991) P-Z, pp. 53-101. Se centra en documentos no literarios de carácter jurídico, económico, artístico e histórico: 256 en total, sumando los añadidos a lo largo de todos los artículos. No ofrece definiciones sino agrupaciones de palabras de la misma familia léxica y primeras documentaciones localizadas en textos concretos. Veámoslo: 


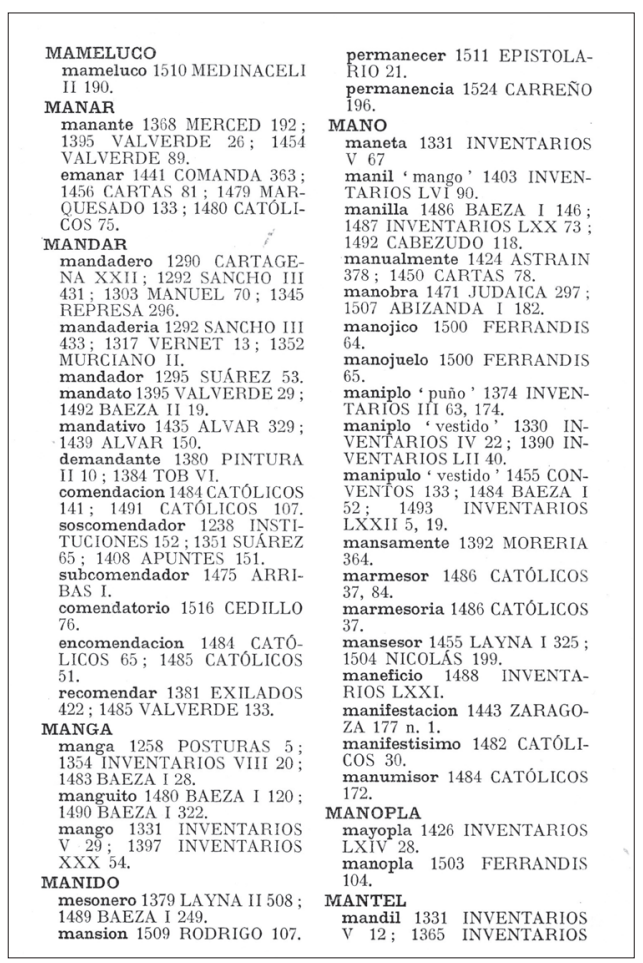

[12] El Dictionary of the Old Spanish Language (DOSL), iniciado por la Universidad de Wisconsin (Madison) ha sido abandonado y transformado en otro "cuya finalidad es registrar el vocabulario de Alfonso X el Sabio".

[13a] Van Scoy, Herbert Allen: A Dictionary of Old Spanish Terms Defined in the Works of Alfonso X, (Madison, 1986), "glosario que da perfecta cuenta, por ejemplo, del modo en que se sistematiza la realidad, a fin de integrarla en las nuevas estructuras de pensamiento surgidas a mediados del s. XIII" ${ }^{10}$. Por el elevado número de cultismos, de extranjerismos y de neologismos de creación romance definidos con toda precisión y claridad, "es de estricta justicia reconocer el inmenso valor lexicográfico de la obra alfonsí: ciertamente Alfonso x no compuso glosario alguno, pero, a lo largo de la vasta producción escrita por su mano o a instigación suya, aparecen definidos centenares de términos, siempre al hilo de lo que se va narrando o explicando" $"$.

[13b] Rubio Moreno, Laura, en su Contribución al estudio de las definiciones léxicas de "Las Partidas" de Alfonso x (Ávila, Fundación Sánchez Albornoz, 1991), contabiliza nada menos que unas mil trescientas.

9 Haensch, G. y Omeñaca, Carlos: Los diccionarios del español en el umbral del siglo XXI. Problemas actuales de la lexicografía, los distintos tipos de diccionarios, una guía para el usuario, bibliografía de publicaciones sobre lexicografia, Salamanca, Universidad, 2004, 2a edición corregida y aumentada.

${ }^{10}$ Gómez Redondo, Fernando, art. cit., p. 234.

11 Bajo PÉrez, Elena, op. cit., 2000, p. 64. 
[13c] ADMYTE - Diccionario de la lengua medieval española, $1^{a}$ etapa: la prosa alfonsí. Madrid, Micronet/Quinto Centenario España/MC/BN, 1992. En CD-ROM.

[13d] SÁnchez GonzÁlez de Herrero, María Nieves (dir.): Diccionario español de documentos alfonsíes, Madrid, Arco/Libros, 2000.

Basado en un corpus de unos seiscientos documentos originales emitidos por la cancillería de Alfonso x. Se recurre a definiciones enciclopédicas en palabras "que o bien no han llegado hasta nuestros días o bien han perdido el significado que presentan en los documentos estudiados, la mayor parte de las veces porque han desaparecido los objetos, acciones o realidades a los que se referían"12. Además, se definen $-\mathrm{y}$ eso sin duda resultará esclarecedor- muchas unidades pluriverbales: hay numerosas construcciones "que hay que definir en su integridad, porque la construcción está tan alejada de la lengua actual que definir palabra por palabra carece de sentido"13. Destacan otras dos características: 1) se lematiza casi siempre según la forma moderna, pero se ofrecen alfabetizadas todas las formas que aparecen en los documentos; 2) cuando se considera oportuno, se remite a otras palabras relacionadas semánticamente ${ }^{14}$.

[13e] Kasten, Lloyd A. y Nitti, John J. (dirs.), Diccionario de la prosa castellana del rey Alfonso X, Nueva York, Hispanic Seminary of Medieval Studies, 2002, vol. I: a-desgajar, vol. II: desgañamiento-nodrecer, vol. III: noemanita-zurriaga. En la "Presentación", O’Neill, John aclara que esta extensa obra (1918 páginas en total) complementa el diccionario anterior [13d]. "Se basa en el léxico de los textos que se han considerado emanados de la cámara regia de Alfonso x, rey de Castilla y León entre 1252 y 1284 . Son, por tanto, en su mayoría textos absolutamente fidedignos (...). Se decidió transcribir ab ovo todos los textos seleccionados para su inclusión (...) (aproximadamente cinco millones de palabras)"15. Incluye numerosas citas ilustrativas que aparecen ordenadas cronológicamente dentro de cada acepción. En algunas entradas, bajo el epígrafe "definiciones indeterminadas", se transcriben citas en las que el lema aparece con un significado que les ha parecido demasiado aventurado deducir por el contexto (por ejemplo, hay diez citas de definición indeterminada sub voce "descubrir"). Por su utilidad, debe destacarse el registro de muchas unidades pluriverbales. Así, sub voce "derecho", se distinguen "a derechas", "a derecho", "derecho comunal", "derecho diocesano", "derecho eclesiástico", "derecho público", "en derecho" (2 acepciones), "en derecho de". En los verbos, que suelen ser voces particularmente polisémicas, la acotación y la definición de las unidades léxicas complejas resultan todavía más iluminadoras; veamos el caso de meter:

12 Sánchez González de Herrero, M. ${ }^{a}$ Nieves: "Problemas de definición en un diccionario de tipo histórico: El Diccionario de la documentación alfonsi”, en FERNÁNDEZ GonZÁLEZ, Jesús et al. (eds.), Lingüística para el siglo XXI, Salamanca, Universidad, 1999, vol. II, pp. 1449-1454.

13 Ibidem, p. 1453.

14 Véase la reseña de GARCíA, Serafina, en Aljamía, 15 (2003), pp. 508-519.

15 En septiembre de 2011 el Hispanic Seminary of Medieval Studies presentó oficialmente el primero de los corpus textuales de la Biblioteca Digital de Textos del Español Antiguo, que es el que corresponde a la obra en prosa de Alfonso X el Sabio: <http://www.hispanicseminary.org/t\&c/ac/index.htm> 


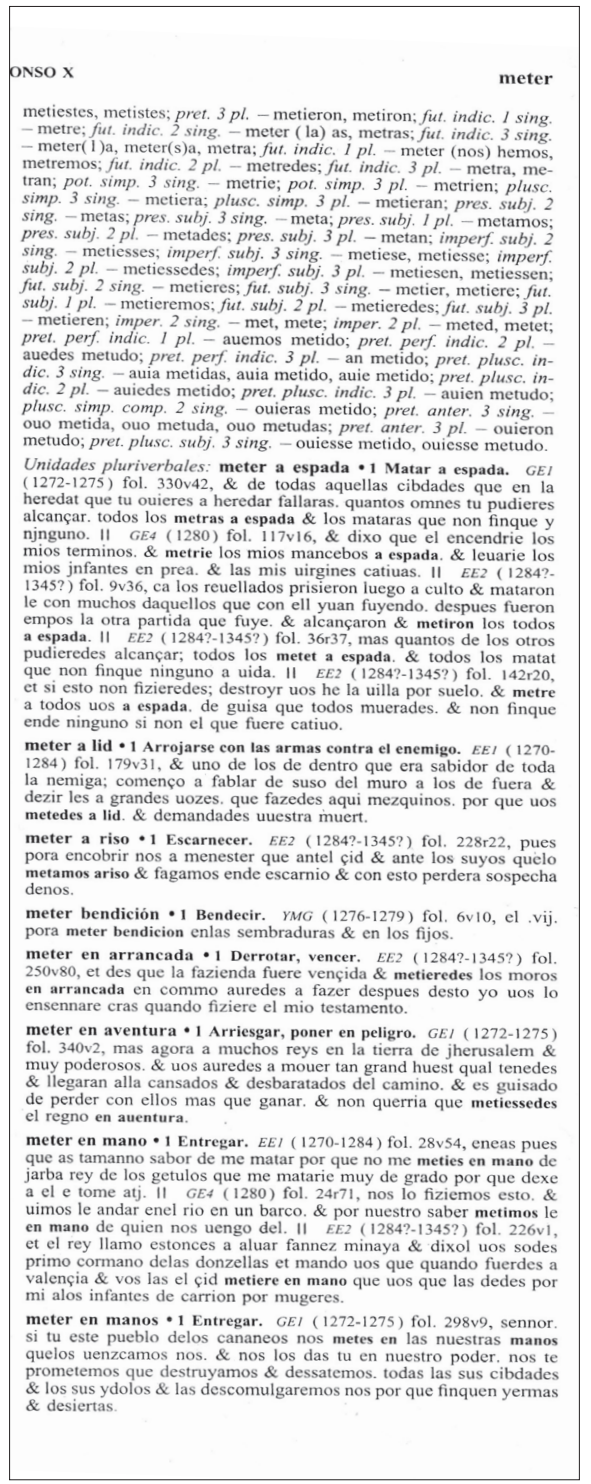

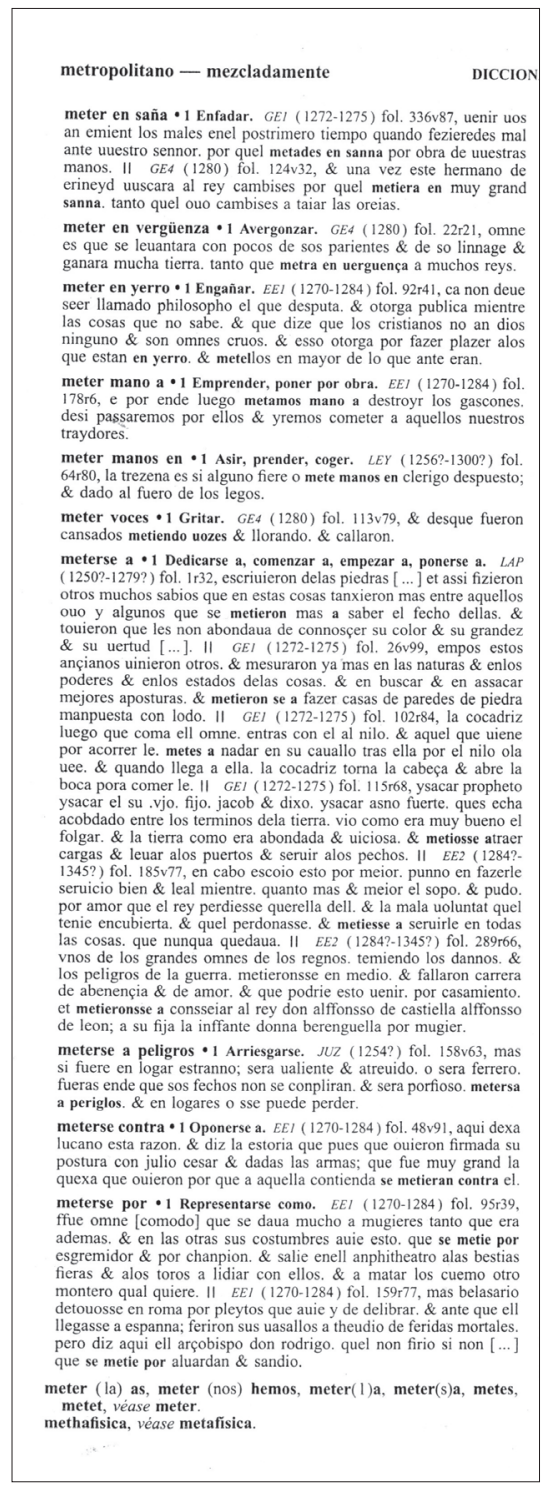

Y todavía alguna más: "meter en culpa" aparece sub voce "culpa", por ejemplo.

[14] Oelschläger, V. R. B.: A Medieval Spanish Word-List. A preliminary Dated Vocabulary of First Appearances up to Berceo. Madison, Universidad de Wisconsin, 1946. Reimpresión facsimilar de 1978. En efecto, registra términos hasta 1220.

[15] Alonso, Martín: Diccionario medieval español. Desde las Glosas Emilianenses y Silenses (s. X) hasta el siglo XV. Salamanca, Universidad Pontificia, 1986, tomo I: $A-C$, tomo II: $C h-Z$. "Martín Alonso sólo ha manejado 46 fuentes directas (incluyendo incunables y primeras impresiones). El resto de la bibliografía, cerca del noventa por 
ciento, son o ediciones de finales del siglo XIX (las más numerosas) o textos editados hasta 1964, cuya fiabilidad es en muchos casos dudosa"16. La selección del corpus, el sistema de transcripción, el tratamiento de los materiales, no responden, desde luego, a las mínimas exigencias lexicográficas actuales. Sin embargo, al igual que sucede con su Enciclopedia del idioma (v. infra [32]), no conviene abandonar una búsqueda infructuosa sin haberlo consultado.

[16a] MüLler, Bodo: Diccionario del español medieval (DEM), Heidelberg, Carl Winter, 1987-2005. 26 fascículos: a-almohatac. Sin duda, esta era la gran obra necesaria para conocer a fondo el vocabulario del español en la Edad Media ${ }^{17}$, pero parece definitivamente interrumpida. El DEM trabajaba sobre todos los textos conocidos, intentando proporcionar una interpretación sintáctica y semántica de toda voz documentada: por eso se atiende incluso a los hápax y se aclaran en lo posible las falsas lecturas (véase almahar2 en la página reproducida a continuación).

\begin{tabular}{|c|c|}
\hline almagre & almaharot \\
\hline almagre $\mathrm{m}$. & tal muger, como ella, et sy la dexare ante que con ella \\
\hline «almazarrón»" & $\begin{array}{l}\text { casare, non le dé nada. - p 31: el omen que non es } \\
\text { para la muger, et casare con ella et despues se quitare }\end{array}$ \\
\hline [c 1350] ConosçimientoMundo p 70: este mare Rubro & della, paguele todo su almahar. - p 32: sy ante que \\
\hline dizen asi porque el suelo del es almagre $z$ tierra & con ella sea entrado se desfiziere el casamiento, non \\
\hline $\begin{array}{l}\text { bermeja } z \text { faze el agua Ruuia } \\
\text { [1408] CirugiaRimada 57r8: Receta sal de espana. }\end{array}$ & $\begin{array}{l}\text { le dé almahar ninguno. }-p 39 \text { : Et sy se desfiziere tal } \\
\text { casamiento despues que fueren en uno, [...], que }\end{array}$ \\
\hline libra j. çera. onça .j. litargio libra .j. trementjna onça & salga este almahar de su terçio, et non de la cabeza \\
\hline j. quina onça $\mathrm{j}$. apopanac onça $\mathrm{j}$. almagre. & $\begin{array}{l}\text { del algo. - p 51: Otrosy, el casamiento del segar es } \\
\text { ninguno; et departese que el que dice á otro: «casame }\end{array}$ \\
\hline & con tu fija, et casarte he con la mia, et non me des \\
\hline $\begin{array}{l}\text { N.: Del árand. almágrah, cl. mag̀(a)rah «tierra roja» } \\
\text { (cf. Corriente Arabismos 185a). }\end{array}$ & $\begin{array}{l}\text { nada, nin te daré nadam, et non declaran los almahares, } \\
\text { estos casamientos sean ningunos, }[\ldots] \text {, asy como }\end{array}$ \\
\hline & dicho es por los forros: "casame con tu fija, casarte \\
\hline & $\begin{array}{l}\text { he con la mia, et non aya almahar entre nosm; estos } \\
\text { casamientos tales sean desfechos. Et sy los almahares }\end{array}$ \\
\hline almaguana $\mathrm{f}$. & fueren buenos, et que ayan puesto sus arras, lo de \\
\hline "cierto tributo o impuesto" & $\begin{array}{l}\text { mano et lo alçado como deven, pase: que los } \\
\text { almahares son de la muger, et contado de su algo. }\end{array}$ \\
\hline [1385] JudenSp 233 p 226: las almaguanas que se cojen & p 60: Et otrosy, sy omen dexare á su esposa ante que \\
\hline de la carne que se mata en la juderia de Toledo. & $\begin{array}{l}\text { se ençierre con ella, et oviere sobre él almahar cierto, } \\
\text { tomará la meitad de lo que es á dar de mano - p } 235\end{array}$ \\
\hline & et esto despues que la preguntó, et la fizo sabidora \\
\hline \multirow{2}{*}{$\begin{array}{l}\text { N.: Se relaciona tal vez con el ár. ma'una «provisions } \\
\text { de bouche, vivres» (cf. A. de Biberstein Kazimirski, } \\
\text { Dictionnaire Arabe-Français, Paris } 1860 \text { [reimpresión } \\
\text { por: Librairie du Liban, Beyrouth, s.a.], tomo II 1169a). }\end{array}$} & $\begin{array}{l}\text { del dicho fulan su marido, et quel farie almahar con } \\
\text { él, et plogol con todo esto }\end{array}$ \\
\hline & N.: Del ár. al-mahr «dote» (R.G. Khoury). \\
\hline \multicolumn{2}{|l|}{ almahalen $\mathrm{m}$. } \\
\hline \multirow{6}{*}{$\begin{array}{l}\text { "cerezo de Santa Lucía (Prunus mahaleb, L.)» } \\
\text { [c 1300] AgriculturaBasșál p } 403 \text { : E los arboles de la } \\
\text { goma son los albarcoques e los almendrales e los } \\
\text { ceresos e los çiruelos e los priscales e el almahalen e } \\
\text { los que les semejan. }\end{array}$} & almahar $2 \mathrm{~m}$ \\
\hline & "torre de una mezquita, alminar» \\
\hline & [a 1330?] LeyesMoros p 155: Otrosy, todas las juras \\
\hline & en todos los dichos son et non mas; et juren las gentes \\
\hline & $\begin{array}{l}\text { en ralmagid, et non juren çerca ningunt almahar de } \\
\text { los almahares, salvo en el almahar del anaby; et non }\end{array}$ \\
\hline & juren en el logar, sy non por quarto de dobla, et jurarán \\
\hline \multirow{3}{*}{$\begin{array}{l}\text { N.: Cf. la nota del editor al pie de la página: „Está [sc. } \\
\text { almahalen] por almahaleu, [...] o cerezo de Santa } \\
\text { Lucía." Vid. tb. Capuano Agriculture, s.v. almahalen. } \\
\text { Del ár. al-mahaleb. }\end{array}$} & por menos de aquello en los otros almagides. \\
\hline & \\
\hline & N.: Se trata prob. de una mala lectura por almanar. \\
\hline & La forma parece relacionarse con el ár. al-manärah \\
\hline \multirow[b]{2}{*}{ almahar $1 \mathrm{~m}$. } & \\
\hline & almenara I y p $193 \mathrm{~b}$ s.v. alminar. Vid. tb. almenara. \\
\hline «dote que el novio entrega a la novia antes de casarse; & \\
\hline $\begin{array}{l}\text { carta dotal" } \\
\text { [a 1330?] LeyesMoros p 16: Las adelantanças ó los }\end{array}$ & almaharot $\mathrm{m}$. \\
\hline testimonios, ó los almohares [sic] cunplen para los & \\
\hline casamientos - p 22: el que casare con muger et le & "raiz del laserpicio" \\
\hline feziere almahar de enganno, que le pague lo que & [1250] LAnimalias 76v23: tomen [ $\ldots$ ] dela pimienta. i. \\
\hline dixiere, $[\ldots]$. Et sy contia de dineros non nombrare & onça. e del aloen. e del forbio e del almaharot de \\
\hline en él, quel ponga por almahar asy como ponen á otra & cada uno una onça. $-76 \times 29:$ o tomen de la pimienta \\
\hline & \\
\hline
\end{tabular}

16 Gómez Redondo, Francisco: “art. cit.”, p. 237.

17 Bajo Pérez, Elena: "Reseña del Diccionario del español medieval de Bodo Müller", Romanische Forschungen, 118/4, 2006, pp. 486-491. En esta reseña se analizan con detalle las principales características del DEM, y se ejemplifican a través de los fascículos 21-26 (2001-2005). 
[16b] Existe también el DEMi, el Tesoro DEM Informatizado (http://www.adw.uniheidelberg.de/dem/fichero/ficherof.html), que permite acceder a los lemas de las palabras comenzadas por $b$-, $d$-, $f$ - y $g$-. No aparecen definiciones, pero sí localizaciones en textos medievales concretos.

[16c] Tras la interrupción definitiva del $D E M$, se barajaron varios destinos para el ingente material reunido en Heidelberg, incluyendo distintas universidades y centros españoles; al final, todos los materiales han sido transferidos a otra universidad alemana, la de Paderborn, con la intención de publicarlos digitalmente bajo el título Archivo Digital del Español Medieval (ADEM). Puede consultarse un buen resumen de este proyecto en ARNOLD, Rafael: "Lexicografría histórica del Judeo-Espanyol - presentación del proyecto ADEM", Sephardica 5 (2011), pp. 279-285. Habrá que estar pendiente de la publicación de estos materiales, pues, dejando de lado libros y documentos, solo el fichero contiene más de medio millón de fichas relativas al léxico de textos literarios, jurídicos, historiográficos, técnicos y científicos de la Edad Media. Para hacerse una idea de la magnitud de esta aportación, conviene recordar que, en los fascículos publicados del DEM, más del veinte por ciento del vocabulario no había sido registrado hasta entonces, al igual que una ingente cantidad de acepciones nuevas. El ADEM facilitará el lema, la categoría gramatical, la primera documentación, las variantes gráficas y la ubicación en la línea del texto correspondiente. Además, mediante un enlace, se podrá acceder a un contexto más amplio, pues "los textos correspondientes ya han sido escaneados y están disponibles como archivos de imagen" ("art. cit.", p. 281).

[17] Serradilla, Ana María: Diccionario sintáctico del español medieval. Verbos de entendimiento y lengua, Madrid, Gredos, 1996. Su planteamiento básicamente gramatical quizá lo aleja de los intereses de los historiadores.

[18] Gutiérrez Tuñón, Manuel: Diccionario de castellano antiguo, [Cuenca], Editorial Alfonsípolis, 2002. Es una obra meramente divulgativa, que solo pretende facilitar un primer acercamiento a los textos antiguos (especialmente, a los medievales).

[19a] Boggs, Ralph Steele, Kasten, Lloyd A., Keniston, H. y Richardson, H. B.: Tentative Dictionary of Medieval Spanish, Chapel Hill, 1946. Constituyó un intento muy parcial, pues es el resultado de fundir únicamente los vocabularios del Cantar de Mio Cid, de la obra de Berceo, del Libro de Apolonio y del Libro del Conde Lucanor.

[19b] Se ha publicado una $2^{\mathrm{a}}$ edición muy ampliada de Florian, Cody y Kasten, Lloyd A., Nueva York, Hispanic Seminary of Medieval Studies, 2001. Esta segunda edición se basa en 80 textos medievales, de los que el más antiguo es el Poema de mío Cid y el más moderno las Fábulas de Esopo (1489): además de textos literarios, hay fueros, himnos, biblias, ordenanzas, etc. Veamos alguna entrada: 
forro (foro) [ár. hurr] (Salvador, L. Serr., 1074, Oel)1. m. horro, hombre libre, Bup 34,9; Apa I 25c15; Apc 139b25; Aju 253b13; Ata 223,19; Aes 119,12; Age IV 235b7. 2. adj. libre (voluntad), Flf 70,9. 3. adj. libre (de esclavitud), $C B a$ $103 \mathrm{c} 37$.

fort véase fuerte (Tudela, Esp. Sg. 50, 1115, Oel)

fortaleçer [cast. fortaleza] v.r. cobrar vigor, Cab 67,19.

fortaleçido [cast. fortaleçer] adj. reforzado, Apc 740b39.

fortalesçemiento véase fortalezamiento

fortaleza (fortalesa) [lat. ${ }^{*}$ fortalicia] (Blo 165, Oel) $f .1$. fuerza, Bsl 71c; Flf 27,16 (fortalesa); AAl 19a7; Aas III 212,7; Aju 91b5; Ala 2r7; Apc 482b15; Api 13b17; Ase 7,29; Cal 139,16; Cas 31,15; Bib I.1.2 Rom 8:38; Mce 517,12; Mar 679,34; Lba 1592c (fortalesa); Stp 182; Yso 91r7. 2. plaza fortificada, fuerte, Apo 615a; Aas I 98,14; Aes 89,19; Age I 199a31; Ase 16,8; Cas 102,32; Mce 511,5; Min 34,5; Luc 8,26; FGz 672d. 3. armamento (pl.), Age I 310b52; Apc 661a7. 4. perseverancia, firmeza, Age IV 61b16; Apa I 96d32; Ase 260,9; Apc 29a35; Mes 283,25.

5. rigor, Aju 65a23; Apa I 85c29; Ala 16c10; Mes 124c28. fortalezamiento (fortalesçemiento) [cast. fortaleza] $\mathrm{m}$. firmeza, resolución, fuerza, $A p c 748 \mathrm{a} 31$ (var. fortalesçemiento).

forte véase fuerte

[20] Léxico hispánico primitivo (siglos VIII al XII). Obra realizada por Rafael LAPESA, con la colaboración de Constantino GARCíA, proyectada y dirigida inicialmente por Ramón Ménendez Pidal. Aunque se publicó en 2003, en una edición de Espasa Calpe, al cuidado de Manuel SECo, es una obra terminada en 1976: cuando se complete su actualización y revisión (ya comenzadas hace años pero todavía lejos de su conclusión), cambiará de nombre y se titulará Glosario del primitivo léxico iberorrománico. En palabras de Villaverde Amieva, Juan Carlos, el LhP "reúne un caudal extraordinario del léxico de los romances iberorrománicos primitivos procedentes de fuentes no literarias (notariales y jurídicas, sobre todo, y en menor medida históricas), (...) desde el siglo vIII al siglo XII, a la vez que comprende la totalidad de las áreas lingüísticas norteñas, fundamentalmente astur-leonesa, castellana y navarro-aragonesa, con menor representación también del área galaico- 
portuguesa y todavía en menor medida de la catalana, a las que se agregan también los materiales sui generis de las mozarabías de al-Andalus" "18.

\begin{tabular}{|c|c|}
\hline pedaszo & 466 \\
\hline 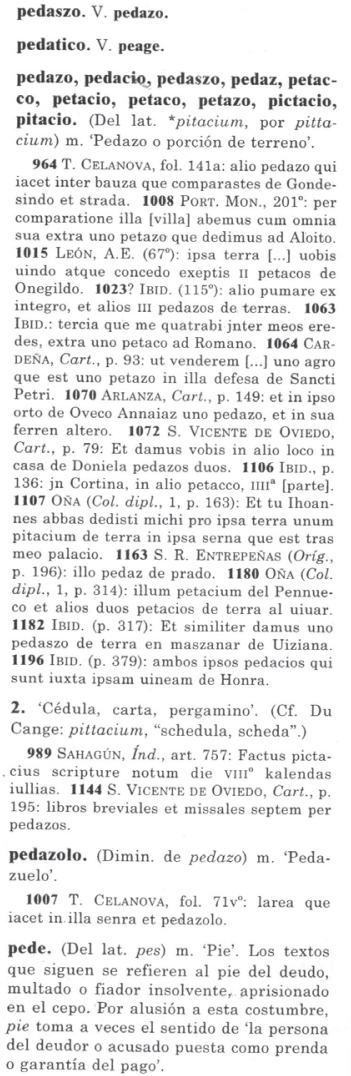 & 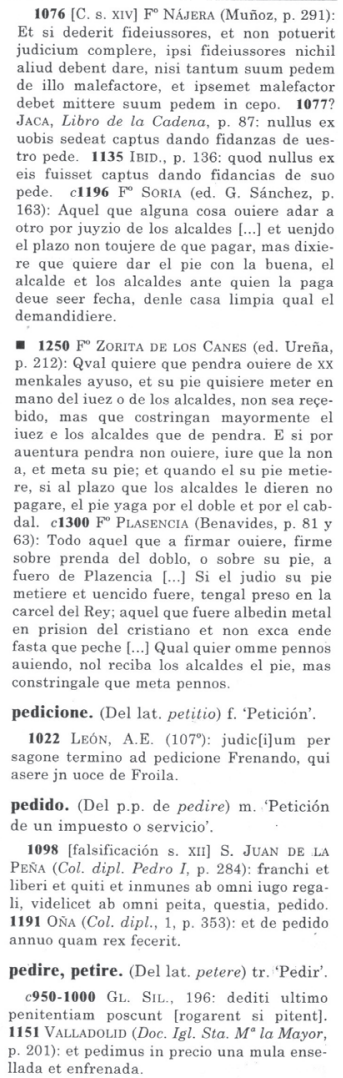 \\
\hline
\end{tabular}

[21a] Gual Camarena, Miguel: Vocabulario del comercio medieval, Barcelona, El Albir, 1976.

[21b] Gago Jover, Francisco: Vocabulario militar castellano (siglos XIII-XV), Granada, Universidad, 2002.

[22] Herrera Hernández, María Teresa (dir.): Diccionario general de los textos médicos antiguos, Madrid, Arco/Libros, 1996.

Ha sido elaborado sobre un corpus de una treintena de obras médicas, casi todas del siglo $\mathrm{XV}^{19}$. Como aclara una de sus redactoras:

18 Véase su reseña del LHP en Aljamía, 17 (2005), pp. 421-438.

19 Desde marzo de 2012 puede consultarse en línea el corpus completo de textos médicos: <http://www. hispanicseminary.org/t\&c/med/index.htm>. Los 55 manuscritos y libros impresos (más de 2.500.000 millones de palabras) incluyen tratados generales (aquellos que pretenden ofrecer una visión sistemática del campo de la medicina), tratados de temas particulares (enfermedades concretas, métodos de diagnóstico o tratamiento, 
"hemos de definir términos que en buena parte son ajenos a la realidad actual y que, en cambio, se insertan en un contexto y una tradición cultural que no podemos ignorar por completo. Esta es la causa de que en muchos casos haya que optar una definición de carácter enciclopédico en la que, además, se da cierta información sin la que el lector actual difícilmente podría captar el sentido de las citas que acompañan al vocablo" ${ }^{20}$.

[23a] De materia médica de Pedanio Dioscórides Anazarbeo (s. I d. C.). Versión multimedia publicada en 2006, en DVD, por la Universidad de Salamanca, del manuscrito De materia médica (BUSA 2659), en edición de EsTeller, Alejandro. Permite consultar el original y su traducción comentada (a cargo de CoRTÉs GABAUdÁn, Francisco y López EIre, Antonio). Contiene numerosos índices y estudios: V. el de Gutiérrez Rodilla, Berta e Hinojo, Gregorio, para comprender la importancia de la obra de Dioscórides durante toda la Edad Media. Salamanca, Universidad, 2006.

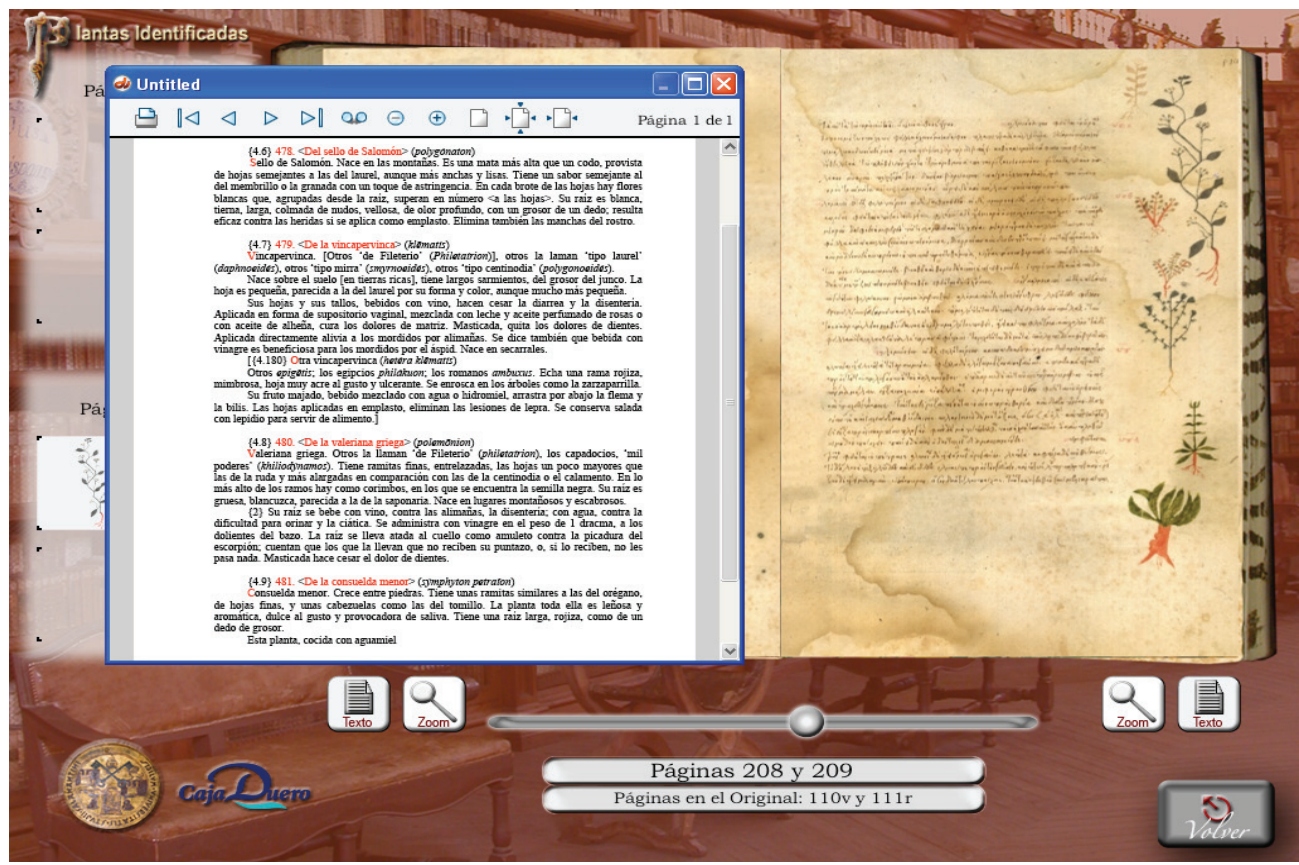

[23b] Existe también una versión de esta edición en red: <http://dioscorides.usal.es>: resulta sumamente fácil y cómodo ir de la traducción española al texto original

sustancias terapéuticas, parto, enfermedades infantiles, peste), colecciones de recetas (textos que explican la preparación de remedios o las propiedades terapéuticas de las sustancias, herbarios y lapidarios), regímenes y guías de salud (textos que proporcionan guías para la preservación de la salud, o que se enfocan en la medicina preventiva), y tratados anatómicos y quirúrgicos.

20 SÁnchez González de Herrero, M. ${ }^{a}$ Nieves: "Los problemas de definición: ¿diccionario de lengua o de habla?", en Villegas, J. (ed.), Actas del XI Congreso de la Asociación Internacional de Hispanistas, Irvine, University of California, 1994, vol. I, pp. 82-89. 


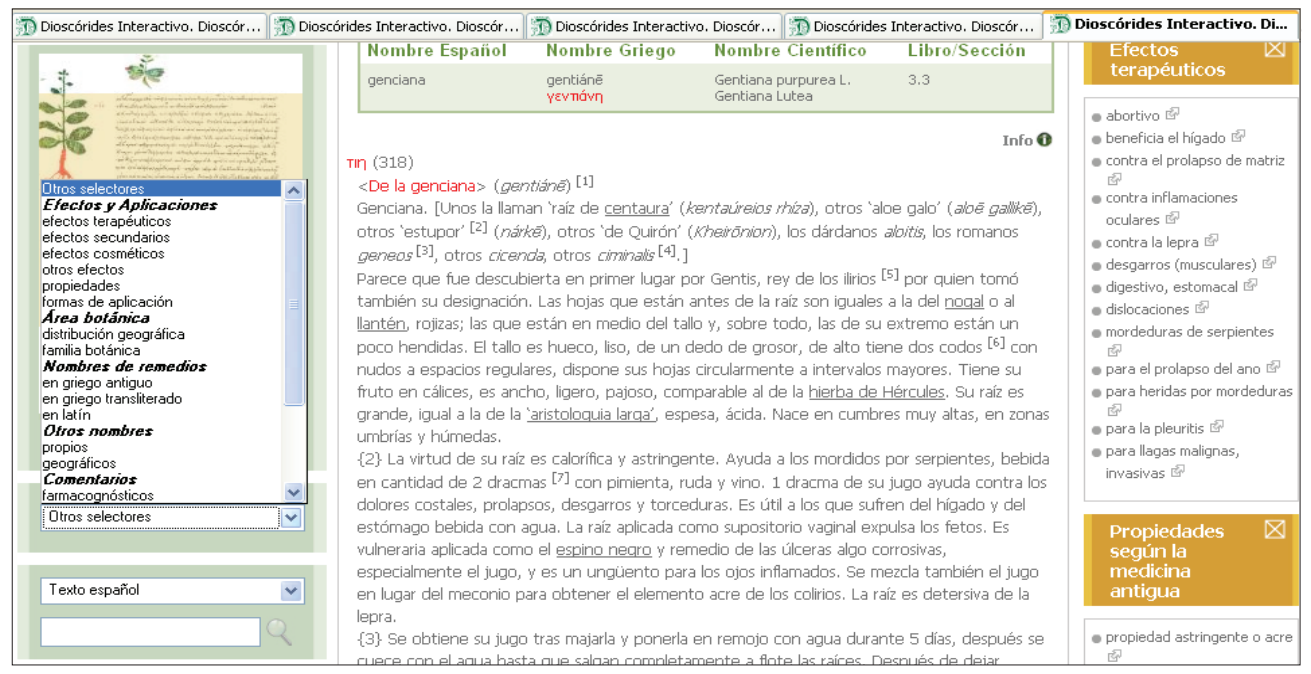

[24] Mancho Duque, María Jesús (coord.): Diccionario de la ciencia y la técnica en el Renacimiento (DICTER), Salamanca, Universidad, 2012. En línea: <dicter.usal.es> Pese a no basarse en textos anteriores al siglo XvI, puede interesar a los medievalistas por su estructuración en doce áreas temáticas representativas de la ciencia (con la excepción de la medicina y ciencias afines) y de la técnica. Es, además, un diccionario ilustrado. El DICTER, como el Diccionario de Terreros (recogido tanto en el NTLLE como en el NTLE, vease infra [30] y [31] ), presta atención a una parcela del vocabulario por lo general ignorada o preterida.

\subsection{GLOSARIOS DE OBRAS (Y DE AUTORES) DE LA EDAD MEDIA}

Así pues, los diccionarios centrados en el léxico medieval, bien por no haberse concluido, bien por ser de naturaleza parcial, no han conseguido registrar, ni exhaustiva ni representativamente, el vocabulario de la época. También estamos lejos de contar con glosarios y concordancias comentadas de todas las obras medievales, ni siquiera de las más importantes. De la antigua recopilación de Dworkin, Steven N. y BILLICK, David J., Lexical Studies of Medieval Spanish Texts. A Bibliography of Concordances, Glossaries, Vocabularies and Selected Word Studies. ( $2^{\mathrm{a}}$ ed., revisada y ampliada. Madison, HSMS, 1993) existe en la actualidad una versión actualizada disponible en $<$ http://www.hispanicseminary.org/lexical-es.htm>, a cargo del mismo Dworkin y de GAGO-Jover, Francisco.

Los glosarios son estos:

[25a] Aguado, J. M. a: Glosario sobre Juan Ruiz, Madrid, Espasa Calpe, 1929.

[25b] Alvar Ezquerra, M. y Miró Domínguez, A.: Concordancias e índices léxicos de la "Vida de San Ildefonso", Málaga, Universidad, 1980. 
[25c] Bartha, J. K.: Vocabulario de los "Milagros de Nuestra Señora" de Gonzalo de Berceo, Illinois, Applied Literature Press, 1980.

[25d] Carrasco Santos, Pilar y Carrasco Santos, Inés: Estudio léxico-semántico de los fueros leoneses de Zamora, Salamanca, Ledesma y Alba de Tormes: concordancias lematizadas, Granada, Universidad, 1997.

[25e] Coullaut cordero, Jaime, Gómez Martínez, Marta, Lleal Galcerán, Coloma, Rubio Moreno, Laura y Sánchez González de Herrero, Ma Nieves: Glosario de la versión castellana de fray Vicente de Burgos del De Proprietatibus Rerum de B. Ánglico [en línea] <http://campus.usal.es/gedhytas>. Sobre el incunable 1884 de la Biblioteca Nacional, 1494.

[25f] Dement, R. D.: An etymological lexicon of "El poema de Alfonso Onceno", Michigan, University Microfilms, 1984.

[25g] Fernández Llera, V.: Gramática y vocabulario del Fuero Juzgo, Madrid, Imprenta Clásica Española, 1929.

[25h] Ganansia, A. G.: Morfología, aspectos dialectales y vocabulario de la "Fazienda de Ultramar", Michigan, University Microfilms, 1971.

[25i] García Martín, J. M.: Concordancias de las "Cantigas de escarnio y de mal dizer”, Alcalá, Universidad, 1997. Microficha.

[25j] GiLKInson, J. E.: A lexicon of the aragonese scriptorium manuscripts of Juan Fernández de Heredia, Michigan, University Microfilms International, 1984.

[25k] Gordillo VÁzquez, M. a del C.: El léxico de "El laberinto de Fortuna”, Córdoba, Universidad, 1992.

[25I] Huerta TejadAs, F.: Vocabulario de las obras de don Juan Manuel (1282-1348), Madrid, BRAE, 1956.

[25m] Keller, Julia: Contribución al Vocabulario del "Poema de Alixandre (sic), Madrid, Tipografía de Archivos, 1932.

[25n] Lanchetas, R.: Gramática y vocabulario de las obras de Berceo, Madrid, Sucesores de Rivadeneyra, 1900.

[25ñ] LitTLefield, Mark G.: Escorial Bible I.ii.19. Edition, study and notes, Madison, Hispanic Seminary of Medieval Studies, 1992.

[25o] LittLefield, Mark G.: Escorial Bible I.I.7. Edition, study, notes and glossary, Madison, HSMS, 1996.

[25p] Márquez Gallego, B.: Léxico del Cancionero de Baena, Córdoba, edición del autor, 1992.

[25q] Menéndez Pidal, R.: Cantar de Mio Cid. III: Vocabulario, Madrid, Espasa Calpe, 1945.

[25r] Montgomery, Thomas A.: El Evangelio de San Mateo según el manuscrito escurialense I.I.6. Texto, gramática, vocabulario, Madrid, RAE, 1962.

[25s] Montgomery, Thomas A., Baldwin, Spurgeon W.: El Nuevo Testamento según el manuscrito escurialense I.I.6. Desde el Evangelio de San Marcos hasta el Apocalipsis [versión castellana de hacia 1260], Madrid, RAE, 1970. 
[25t] Montoya Ramírez, M. I.: Léxico del libro de la montería de Alfonso XI, Granada, Universidad, 1990.

[25u] Pérez Raoul, M.: Vocabulario clasificado de Kalila et Digna, Chicago, University, 1943.

[25v] Richardson, H. B.: An Etymological vocabulary to the "Libro de Buen Amor", New Haven, Yale University Press, 1920.

[25x] Sas, L. F.: Vocabulario del "Libro de Alexandre", Madrid, brae, 1976.

[25y] Steiger, A.: "Contribución al estudio del vocabulario del Corbacho", Boletín de la Real Academia Española, IX, 1922, pp. 503-525; X, 1923, pp. 26-54, 158188 y $275-293$.

[25z] Stinson, B. R.: An etymological lexicon of manuscripts " $A$ " $y$ " $B$ " of "Calila e Digna”, Michigan, University Microfilms, 1984.

Además, existen repertorios léxicos que recogen palabras comentadas en notas a pie de página (o en artículos) de diversos textos. Son útiles sobre todo en la búsqueda de voces raras y curiosas:

[26a] Fontecha, C.: Glosario de voces comentadas en ediciones de textos clásicos, Madrid, CSIC, 1941.

[26b] Jammes, R. y Mir, M.-T. (coords.): Glosario de voces anotadas en los cien primeros volúmenes de Clásicos Castalia, Madrid, Castalia, 1993.

[26c] Romera-Navarro, M., Registro de lexicografía hispánica, Madrid, csic, 1951 (anexo LIV de la $R F E$ ).

\subsection{DICCIONARIOS GENERALES}

Después de revisar todas las obras anteriores, salta a la vista que no disponemos todavía de un diccionario del español medieval completo mínimamente fiable, ni de glosarios o vocabularios de todos los textos, ni siquiera de los literarios. Por lo tanto, un medievalista debería familiarizarse con otras obras lexicográficas, aunque no se ocupen solo del léxico de la Edad Media. Las siguientes son de consulta obligada:

[27] Diccionario histórico de la lengua española (DHLE), de la RAE, Madrid, Imprenta Aguirre, 1951-1996, tomos I-IV: a-apasanca y b-bajoca. Por el planteamiento, por la exhaustividad ${ }^{21}$, por el tratamiento del significado, por todo, constituiría junto al $D E M$ la obra de consulta por excelencia para un medievalista, pero tam-

21 En sentido estricto, el registro exhaustivo de las voces, propio solo del DHLE y del DEM, exige tener en cuenta todas las voces atestiguadas, con independencia de su frecuencia de uso. Esto marca una diferencia fundamental, pues, como recuerda Müller, Bodo (“art. cit.”, p. 68), “...buena parte del vocabulario medieval consta de hápax legomena, es decir, creaciones espontáneas sin pervivencia, derivados y préstamos atestiguados una sola vez, y finalmente también formas dudosas, errores de copista, lecturas equivocadas, palabras fantasma, conjeturas de editores, etc.". 
bién se encuentra interrumpido (desde 1996) y nada permite pensar que podamos disponer pronto de un nuevo diccionario histórico. Ahora es consultable en red, a través de la página de la RAE: <www.rae.es $>$

[28] Diccionario crítico etimológico castellano e hispánico, de Corominas, Joan (con la colaboración de Pascual, José Antonio), Madrid, Gredos, 1980-1991.

[29] Diccionario etimológico español e hispánico, de García De Diego, Vicente, Madrid, SAeta, 1954. $2^{\text {a }}$ ed. muy aumentada por García De Diego, Carmen, con materiales inéditos del autor, Madrid, Espasa Calpe, $1985^{22}$.

[30] Nuevo Tesoro Lexicográfico de la Lengua Española, de la RAE, Madrid, Espasa, 2001, editado en dos DVD: DVD1: $A-F$, DVD2: $G-Z$. Incluye casi todos los diccionarios monolingües y bilingües de los siglos XV-XVIII, casi todos los diccionarios generales no académicos de los siglos XIX y XX (hasta 1918) y casi todos los diccionarios académicos (desde el Diccionario de Autoridades hasta la $21^{\text {a }}$ ed. del DRAE, el primer Diccionario Histórico, 1933-1936: a-cevilla, y todas las ediciones del Diccionario Manual; solo excluye el Diccionario Histórico, 1951-1996: a-apasanca y b-bajoca, que ahora se puede consultar en línea). No debe olvidarse que, además del Diccionario Histórico de 1951-1996, únicamente los diccionarios académicos incorporados en el NTLLE son consultables en línea: <www.rae.es>, los restantes solo aparecen en los DVD mencionados. En cierto modo, se le ha reprochado que "el escaneado de las páginas que componen cada una de las 66 obras constituye en este caso más que nunca una reproducción fiel y exacta de las mismas, sin que haya ningún tipo de diferencia ni de empleo de colores u otras marcas (...). Esto hace del NTLLE una obra electrónica en la que se ha aplicado un nivel más básico de digitalización" ${ }^{23}$. Sin embargo, en nuestra opinión, la posibilidad de ver de verdad las páginas de cada obra como si las tuviéramos delante en papel, supone una ventaja inmensa (y un genuino placer, además): no se pierde información alguna, ni nombres propios, ni marcas de restricción de uso, ni información enciclopédica, etc., y lo más importante: resulta muy cómodo y rápido saber a qué obra corresponde cada consulta, ventaja no desdeñable en un tesoro de muchos diccionarios. Se puede buscar a la vez en todos los diccionarios, o limitar la búsqueda a grupos de diccionarios, a períodos temporales concretos. Es enorme el ahorro de tiempo y de esfuerzo que implica poder consultar juntas tantas obras (no siempre disponibles en ediciones modernas o accesibles). En el ejemplo siguiente, hemos seleccionado "mano", en el grupo DICCIONARIOS DE LOS SIGLOS XV-XVIII: comprobamos que la palabra "mano" está registrada en todos los diccionarios monolingües y bilingües de ese período que figuran en la columna de la izquierda. En el recuadro de la derecha, se ve "mano" tal como aparece en el Ms. 6929 de la BN, de la obra lexicográfica de Francisco del Rosal, datada aproximadamente en 1611 e inédita hasta 1992.

22 Para [27]-[29], véase Porto Dapena, José-Álvaro: "Diccionarios históricos y etimológicos del español”, en Lexicografia y metalexicografia. Estudios, propuestas y comentarios, A Coruña, Universidade, 2009, pp. 215-231.

23 Águila Escobar, Gonzalo: Los diccionarios electrónicos del español, Madrid, Arco/Libros, 2009; especialmente pp. 56-62. 


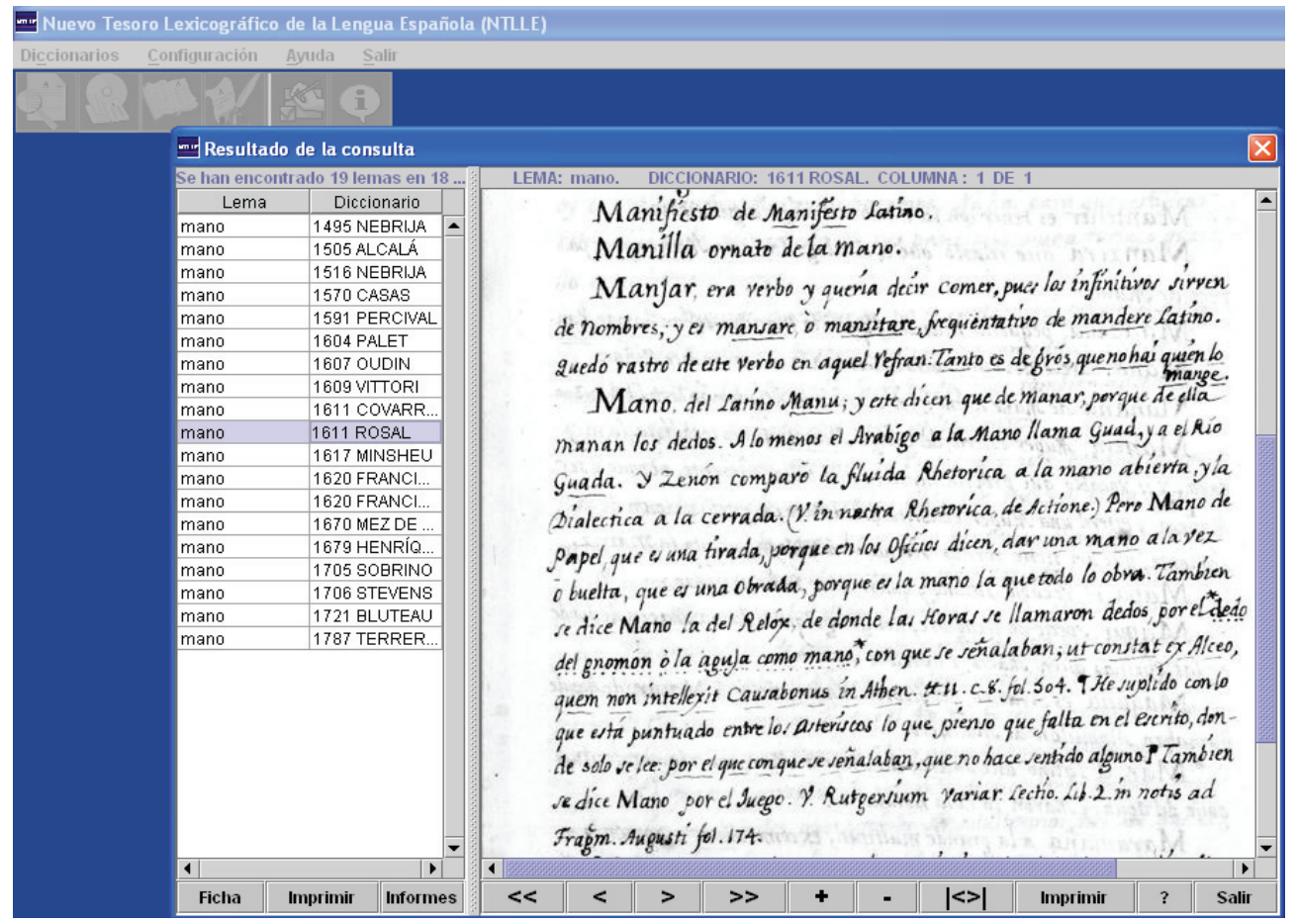

[31] Nuevo Tesoro Lexicográfico del español (s. XIV-1726), dirigido por NIETo, Lidio y Alvar, Manuel: Madrid, Arco/Libros, 2007. Vol. 1. [A-apero] -- Vol. 2. [aperr-B] -- Vol. 3. [C-contrad-] -- Vol. 4. [contraer-D] -- Vol. 5 [E-F] -- Vol. 6. [G-K] -- Vol. 7. [L-N] -- Vol. 8. [O-Q] -- Vol. 9. [R-S] -- Vol. 10. [T-Z] -- Vol. 11. [Índice inverso] Es un tesoro en cualquiera de los sentidos del término, pues consigna nada menos que 145 obras (lexicográficas o con interés para la lexicografía) desde el siglo XIV hasta la publicación del Diccionario de Autoridades (1726-1739). De esas 145, las siguientes son las que se han tenido en cuenta desde los comienzos del quehacer lexicográfico hasta finales del s. Xv:

1) s. XIv: Anónimo, Glosarios latino-españoles de la Edad Media (v. supra [5a, 5b, 5c]) 2) 1433: La Biblia de Alba. An illustrated manuscript bible in castilian. With translation and commentaries by Rabbi Moses Arragel. Commissioned in 1422 by Don Luis de Guzmán and now in the Library of the Palacio de Liria, Madrid, Fundación de Amigos del Sefarad, $1992^{24}$.

${ }^{24}$ Por desdicha, las restantes biblias romanceadas de los siglos XII al XV no incluyen glosario, por lo que sus materiales léxicos no se han tenido en cuenta en el NTLE. No obstante, en $<\mathrm{http}: / / \mathrm{www}$.bibliamedieval.es $>$, página web a cargo del equipo dirigido por ENRIQUE ARIAS, Andrés, ya es posible consultar todos estos textos, y lo que es más importante de cara al estudio léxico, también se puede acceder con facilidad a las concordancias de quince romanceamientos bíblicos. (V. también Pérez Alonso, M. ${ }^{a}$ Isabel: "Las biblias romanceadas medievales o la aventura de traducir la 'verdad hebraica' al castellano", Helmántica, LXII (2011), pp. 391415). 
3) 1481: Nebrija, Elio Antonio de: Introductiones latinae, Salamanca, s. i., 1481.

4) 1485: Gutiérrez Cerezo, Andrés: Breuis grammatica in laudem reuerendissimi episcopi burgensis domini ludouici acuña et rectae et optimae dedicata, Burgos, Fredericus Burgis, 1485.

5) 1490: Fernández de Palencia, Alonso, Universal vocabulario en latín y en romance, (v. supra [7a] y [7b]).

6) 1492: Nebrija, Elio Antonio de: Lexicon hoc est dictionarium ex sermone latino in hispaniensem, Salamanca, s. i., 1492. (v. supra [8a]).

7a) 1493: Nebrija, Elio Antonio de: Introductiones latinae, Burgos, Federicum Alamanum, 1493.

7b) 1495: Nebrija, Elio Antonio de: Introductiones latinae, Salamanca, s. i., 1495.

8) 1495?: Nebrija, Elio Antonio de: Dictionarum ex hispaniense in latinum sermonem, Salamanca, s. i., s. a. [¿1495?] (v. supra [8b]).

9) 1499: Fernández de Santaella, Rodrigo: Vocabularium ecclesiasticum per ordinem alphabeti, (v. supra [9]).

10) s. XV: Anónimo, Vocablos castellanos (v. supra [6]).

En una entrada como "tirano", que reproducimos a continuación, se aprecia el sistema seguido: lema en negrita, variantes entre paréntesis y citas por orden cronológico. Salta a la vista cuánto provecho puede derivarse de la consulta de esta obra.

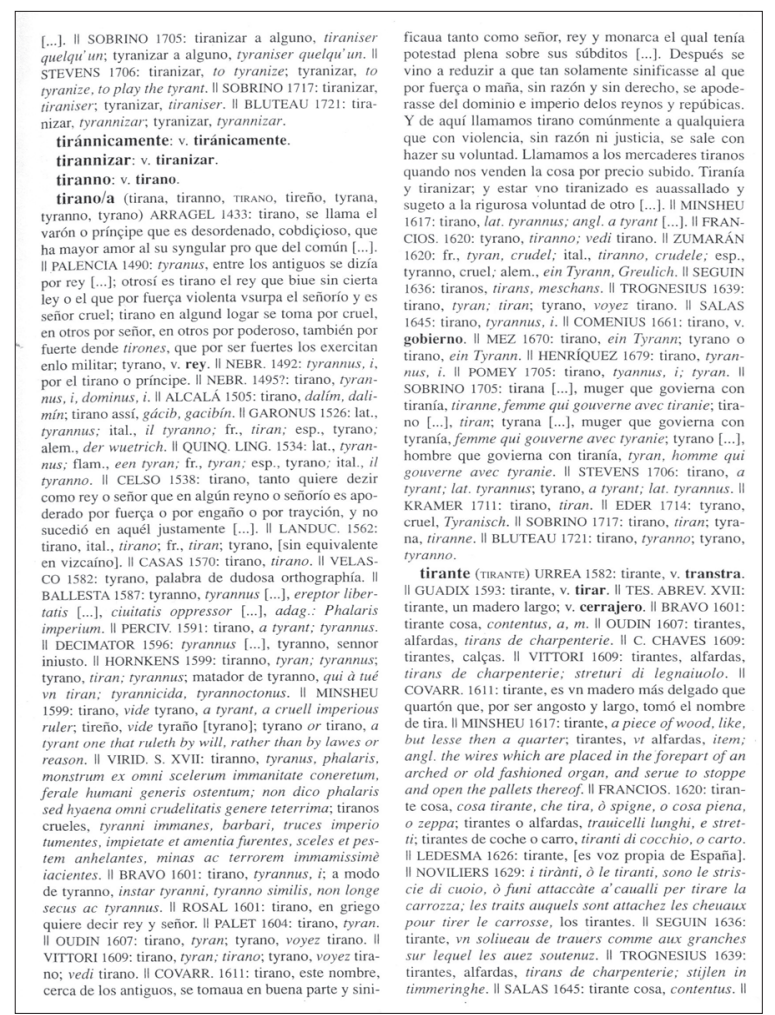


En el Prólogo (p. XI), se advierte de la exclusión de los nombres propios; esto implica pérdida de información enciclopédica, que solo se podrá recuperar consultando las obras directamente o recurriendo al NTLLE (v. supra [30]), si son de las incluidas en él. Más adelante dedicaremos un apartado a la búsqueda de nombres propios. En cualquier caso, el NTLE es una obra fundamental para reconstruir la historia del léxico español; para comprobarlo basta escoger cualquier término no registrado en el $D H$ [27], ni en el DEM [16a], que básicamente se han ocupado de la letra $a-$ :

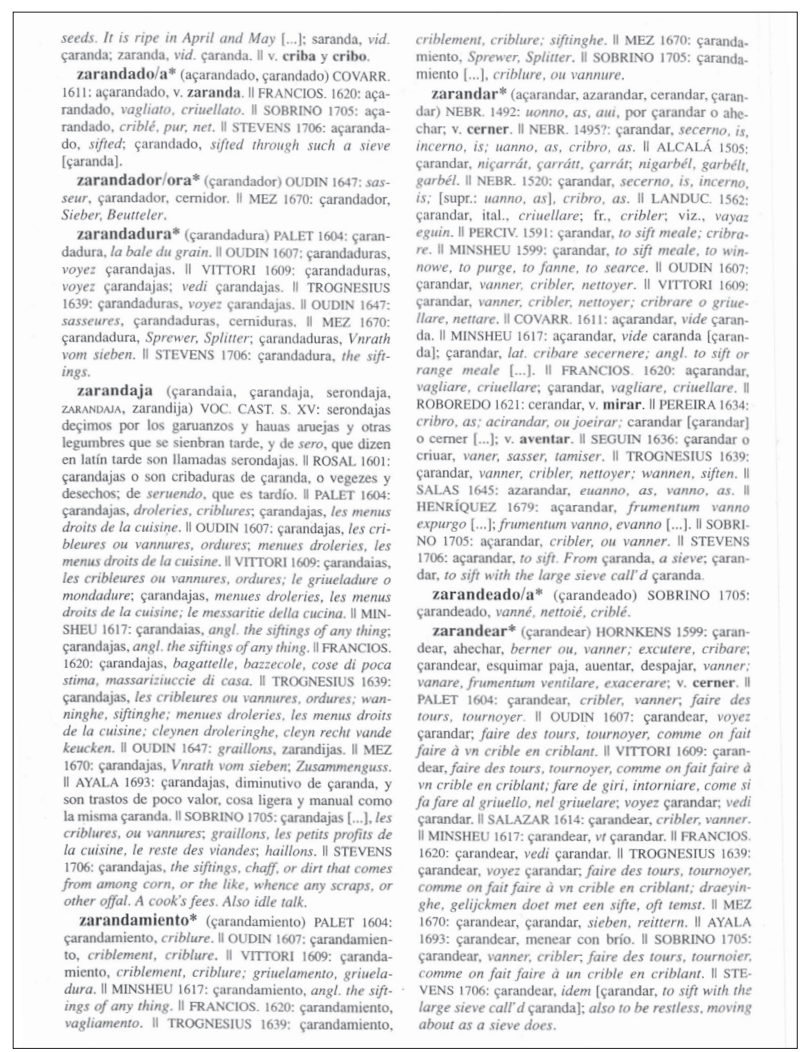

[32] Alonso, Martín: Enciclopedia del idioma. Diccionario histórico y moderno de la lengua española (siglos XII al xx). Etimológico, tecnológico, regional e hispanoamericano, Madrid, Aguilar, 1958. Tres volúmenes. Reimpresiones de 1968 y 1982. Véase supra [15].

\subsection{DICCIONARIOS DIALECTALES}

En el Diccionario Histórico $(D H)$ se justifica por qué el léxico medieval castellano no puede separarse tajantemente de los léxicos leonés y aragonés:

Sabido es que el castellano absorbió los dos dialectos laterales hermanos suyos, el leonés y el aragonés, así como los del mediodía, es decir, los dialectos mozárabes. 
Hasta el siglo XIV hubo literatura en leonés y hasta finales del siglo XV en aragonés; pero casi nunca libre de influencia lingüística castellana. Así pues, gran parte de la literatura medieval del Centro peninsular ofrece este hibridismo; y de igual modo que no se prescinde de ella en una historia de la literatura española, así tampoco debe quedar su léxico fuera del Diccionario Histórico de nuestra lengua, aun cuando su evolución fonética se muestre dispar de la castellana. Igual cabe decir del mozárabe, que si no logró cultivo duradero, da las menciones más antiguas de muchas palabras con exacto paralelo castellano. Por lo tanto, los leoneses avolo, avuolo, el aragonés dreitero o el mozárabe abrewalyo deben figurar, respectivamente, junto a los castellanos abuelo, derechero, abrojo ${ }^{25}$.

En la actualidad, las hablas dialectales conservan muchos arcaísmos perdidos en la lengua general; por eso, no se debe abandonar la búsqueda de una palabra de un texto medieval -y mucho menos si está relacionada con la "cultura material"26 - sin consultar los diccionarios de dialectalismos, regionalismos, etc. Las voces registradas en ellos pueden haber sido siempre exclusivas de áreas geográficas delimitadas dentro de la península (más o menos amplias), pero también pueden ser voces que en siglos pasados hubieran sido de uso general o de uso menos restringido. "Los conceptos de arcaísmo y de regionalismo o localismo frecuentemente se presentan superpuestos"27. Indicamos solo los más generales y accesibles ${ }^{28}$.

[33a] Academia de la Llingua Asturiana, Diccionariu de la llingua asturiana, Uviéu, 200029. Se puede consultar en línea: <www.academiadelallingua.com/ diccionariu/index.php>

[33b] Alcalá Venceslada, Antonio: Vocabulario andaluz, Andújar, La Puritana, 1933; $2^{\mathrm{a}}$ ed.: Madrid, RAE, 1951; edición facsímil con anexo bibliográfico inédito: Jaén, Universidad/Caja Sur, 1998.

[33c] Álvarez Curiel, Francisco: Vocabulario popular andaluz, Málaga, Arguval, 1991.

[33d] Andolz, Rafael: Diccionario aragonés, Zaragoza, Imprenta General, 1977. 4ª ed. corregida y aumentada: Zaragoza, Mira Editores, 1992.

[33e] Badía Margarit, Antonio M.: Contribución al vocabulario aragonés moderno, Zaragoza, CSIC, 1948.

${ }^{25}$ RAE, Diccionario histórico de la lengua española, Madrid, Imprenta Aguirre, 1972, fascículo preliminar, p. IX. Se reproduce toda la introducción en LAPESA, Rafael: "Prólogo al Diccionario Histórico de la lengua española", en Léxico e historia. II: Diccionarios, Madrid, Istmo, 1992, pp. 41-61.

26 "Hay muchos sectores en el léxico de la vida material (piénsese en la vida campesina, en las actividades artesanales o en el folklore) en que el «progreso» ha provocado la pérdida irreversible de muchas palabras (y aun con eso, al menos cabe congratularse de que la etnografía, la dialectología o la geografía lingüística hayan llegado muchas veces a tiempo de salvar al menos la noticia de su existencia)": Álvarez DE MirAndA, Pedro: "Neología y pérdida léxica", en De Miguel, Elena (ed.), Panorama de la lexicología, Barcelona, Ariel, 2009, pp. 133-158.

27 Álvarez de Miranda, Pedro, “cap. cit.”, p. 155.

28 Quedan fuera los centrados en el español de América y de Canarias.

29 Puede verse una reseña detallada de BAJo PÉrez, Elena: en Revista de Filoloxía Asturiana, 2 (2002), páginas 241-255. 
[33f] Calero López de Ayala, José Luis: Vocabulario dialectal del La Mancha conquense, Cuenca, Diputación, 1995.

[33g] Dízz Suárez, María Soledad: Léxico leonés, León, Universidad, 1994.

[33h] Estrella Sevilla, Emilio: Vocabulario murciano, Murcia, edición del autor, 1990.

[33i] Fernández Catón, José María: Index Verborum de la documentación medieval leonesa, León, CEI "San Isidoro"/Caja España/AHD, 1999-2002. Tomo I: Monasterio de Sahagún (857-1300) A-L; tomo II: Monasterio de Sahagún (857-1300) M-Z; tomos III y IV: Archivo de la Catedral de León (775-1300) ${ }^{30}$.

[33j] García Arias, Xose Lluis: Diccionario general de la lengua asturiana, [s.a.], en línea: $<$ http://mas.lne.es/diccionario/intro.php>

[33k] García Lomas, G. A.: El lenguaje popular de las montañas de Santander, Santander, Diputación, 1949.

[33I] García Soriano, Justo: Vocabulario del dialecto murciano, Madrid, Bermejo Impresor, 1932. Reimpresión en Murcia, en 1980.

[33m] Goicoechea, Cesáreo: Vocabulario riojano, Madrid, Anejo del Boletín de la RAE, 1961.

[33n] Gómez Ortín, Francisco; Vocabulario del noroeste murciano, Murcia, Editora Regional de Murcia, 1991. Se puede consultar en línea y descargar en PDF.

[33ñ] González Posada, Carlos: Diccionario de algunas voces del dialecto asturiano, Oviedo, Universidad, 1989.

[33o] Gordaliza, F. R.: Vocabulario palentino, Palencia, Caja, 1988.

[33p] Hernández Alonso, César (coord.): Diccionario del castellano tradicional, Valladolid, Ámbito, 200131.

[33q] Iribarren, José María: Vocabulario navarro y Adiciones al vocabulario navarro, Pamplona, IPV, 1952 y 1958, respectivamente. Nueva edición ampliada a cargo de Ollaquindia, Ricardo: Pamplona, IPV, 1984.

[33r] Le Men, Janick: Repertorio de léxico leonés, León, Universidad, 2003. 3 tomos. [33s] Le MeN, Janick: Léxico del leonés actual, León, CEI "San Isidoro"/Caja España/ AHD, 2002-2012. Tomo I (2002): A-B; tomo II (2004): C; tomo III: D-F; tomo IV (2007): G-M; tomo V (2009): N-Q; tomo VI (2012): R-Z. Muy completo.

30 "Desde el punto de vista léxico, disponemos además de una herramienta especialmente útil como son los Index Verborum, en los que, separados por archivos de procedencia, se han volcado en un índice -con su correspondiente localización- todas las formas o variantes que figuran en varias de las colecciones documentales.", palabras de Morala, José Ramón: "Documentación leonesa y léxico hispánico", en Domínguez García, Manuela et al. (coords.), Estudios dedicados a José María Fernández Catón, León, CEI "San Isidoro", 2004, pp. 1019-1039. Trabajo también disponible en línea. En su reseña de esta obra (Aljamía, 15 (2003), pp. 362-365), Viguera Molins, M. a Jesús insiste en que estos índices “son de referencia obligada” y asegura que "recorrer estos índices constituye una lectura muy provechosa, porque evocan el ámbito cultural, político, económico en que se insertan los documentos en que aparecen".

${ }^{31}$ Puede ser útil aunque no está concebido para consultarse semasiológicamente: no siempre ofrece definiciones de los términos, solo los agrupa por campos temáticos. 
[33s1] LLeal Galceran, Coloma (coord.): Diccionario del castellano del siglo XV en la Corona de Aragón (DicCA-XV). Disponible en red desde diciembre de 2012 en $<$ http://stel.ub.edu/diccaxv>

[33u] Miguélez Rodríguez, Eugenio: Diccionario de las hablas leonesas (Léon, Zamora, Salamanca), Zamora, Ediciones Monte Casino, 1993. Recopila el léxico presente en casi 30 estudios (incluidos vocabularios y glosarios) sobre el habla de distintas zonas.

[33v] Murga Bohígas, A. et al.: Habla popular de Extremadura. Vocabulario, Madrid, Rafael García Plata-Quirós, 1979.

[33w] NeIRA, Jesús y PIÑEIro, $\mathrm{M}^{\mathrm{a}}$ del Rosario: Diccionario de los bables de Asturias, Oviedo, Idea, 1989.

[33x] Novo Mier, Llorienzu: Diccionario xeneral de la llingua asturiana, Oviedo, Asturlibros, 1978.

[33y] Ollaquindía Aguirre, R.: Vocabulario y refranero navarros, Navarra, Gobierno, тсP, 1979, y Selección de vocabulario navarro, Navarra, Gobierno, 1981.

[33z] Panizo Rodríguez, J.: Habla y cultura populares de Castilla y León, Valladolid, Diputación, 1999.

[33aa] Rohlfs, Gerhard: Diccionario dialectal del Pirineo aragonés, Zaragoza, ¿s.1.?, 1985.

[33ab] Rollán Méndez, J. Álvaro y SAstre Zarzuela, Eladio: Hablares: el mundo rural y sus aportaciones al léxico castellano. I, El trabajo; II, El hombre; III, El entorno; IV, La fiesta; V, El yantar; VI, El coloquio; VII, Índice general, [Valladolid], Consejería de Agricultura y Ganadería, 2001-2003.

[33ac] Sáiz Barrio, Miguel Ángel: Léxico cántabro, Santander, Tantín, 1991.

[33ad] SÁnchez Miguel, J.: Diccionario del habla toledana, Toledo, Instituto Provincial de Investigaciones y Estudios Toledanos, 1998.

[33ae] Santos Coco, F.: Vocabulario extremeño, Cáceres, ¿s.1.?, 1910.

[33af] Sarmiento, F. M.: Catálogo de voces y frases de la lengua castellana, ed. y estudio de Pensado, José Luis, Salamanca, Universidad, 1973.

[33ag] Serna, J. S.: Cómo habla La Mancha. Diccionario manchego, Albacete, ¿s.1.?, 1974. $2^{a}$ edición: Villarrobledo, Albacete, Imprenta Cervantes, 1983.

[33ah] Urdiales Yuste, Jorge: Diccionario del castellano rural en la narrativa de Miguel Delibes, Segovia, Instituto Castellano y Leonés de la Lengua, $2006{ }^{32}$.

[33ai] Viudas Camarasa, A.: Diccionario extremeño, Cáceres, Universidad de Extremadura, 1980; $2^{\mathrm{a}}$ ed.: 1988.

[33aj] Yunta Martínez, P.: Conquensismos, Cuenca, Caja de Ahorros, 1978.

También se pueden consultar los atlas lingüísticos, directamente o, con más comodidad, a través de recopilaciones:

${ }^{32}$ Registra y define 329 palabras, "ninguna de estas 329 voces aparece en el Diccionario de la Real Academia Española" (del apartado de "Conclusiones"). 
[34a] alea, Alvar, Manuel (con la colaboración de Llorente, Antonio y Salvador, Gregorio): Atlas lingüístico y etnográfico de Andalucía, Madrid, Universidad de Granada/CSIC, 1961-1973.

[34b] aleanR, Alvar, Manuel (con la colaboración de Llorente, Antonio, Buesa, Tomás y Alvar, E.): Atlas lingüístico y etnográfico de Aragón, Navarra y Rioja, Madrid/Zaragoza, CSIC/IFC, 1979-1983.

[34c] aleCMAN, Atlas lingüistico (y etnográfico) de Castilla-La Mancha, García Mouton, Pilar y Moreno Fernández, Francisco (dirs.), 2003: <http://www.linguas.net/ alecman>

Desde los cuestionarios se puede llegar con suma facilidad a los materiales cartografiados.

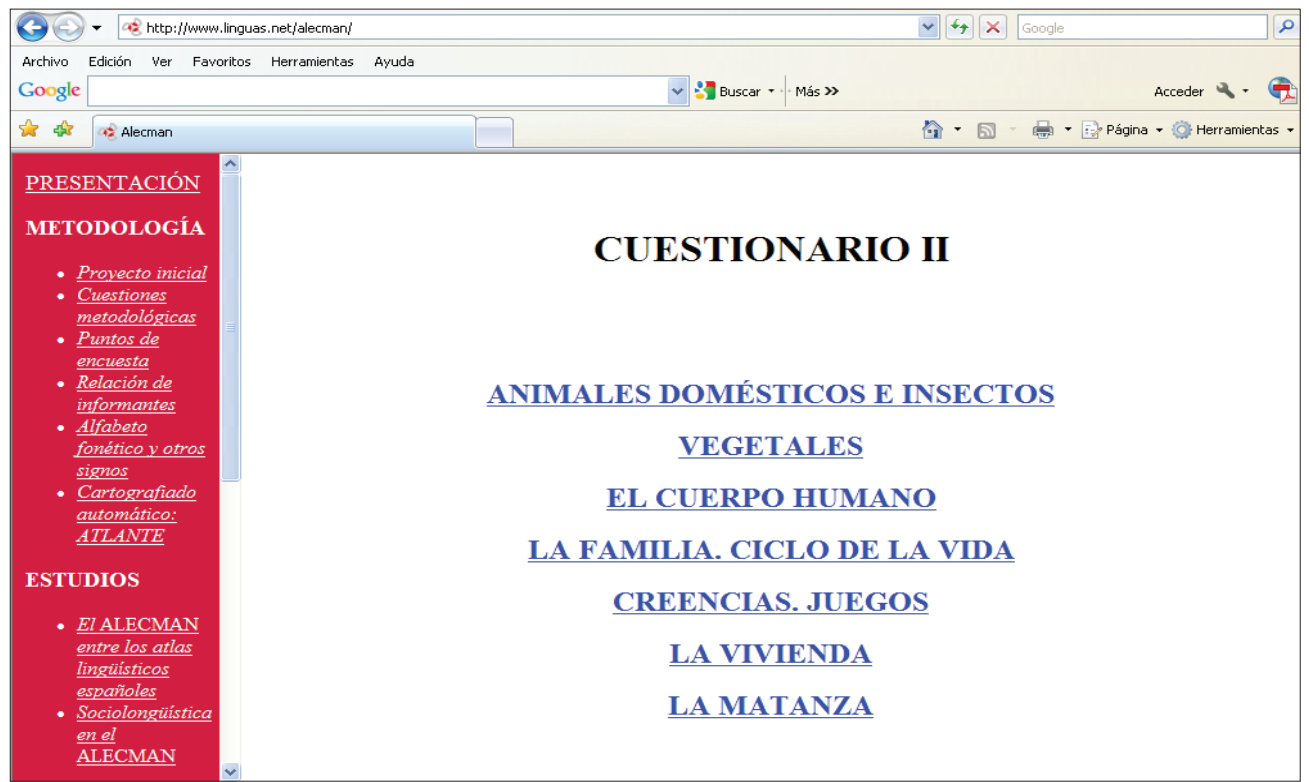

[34d] alPI, Navarro Tomás, Tomás y Balbín, R. (bajo la supervisión de MenÉndez PIDAL, Ramón): Atlas lingüístico de la Península Ibérica, Madrid, CSIC, $1962^{33}$.

[34e] Alvar, Manuel et al. (eds.): Atlas lingüístico y etnográfico de Cantabria, Madrid, Arco/Libros, 1995.

33 "El $A L P I$, como muchos de los atlas lingüísticos realizados desde el nacimiento de la geografía lingüística hasta casi finales del siglo xx, es espejo de una cultura popular en extinción. Los campos léxicos estudiados en este atlas pertenecen a una forma de vida milenaria, en la que los cambios culturales, sociales y lingüísticos se producían de manera parsimoniosa y que en la actualidad se encuentra perdida o en decadencia vertiginosa": Sousa Fernández, Xulio: "Entre el atlas lingüístico y el diccionario de léxico tradicional a partir de los materiales del ALPI", en AHUMADA, Ignacio (ed.): Metalexicografia variacional. Diccionarios de regionalismos y diccionarios de especialidad, Málaga, Universidad, 2010, pp. 237-256. 
[34f] Alvar, Manuel: Atlas lingüistico y etnográfico de Castilla y León, Valladolid, JCyL, 1999.

[34g] Luzón, M. A. y Alvar, Manuel: "Índices léxicos de los atlas lingüísticos españoles”, en Español Actual, 47, 1987, pp. 5-181.

Igualmente, no hay que olvidar que los diccionarios y glosarios de judeoespañol pueden ser útiles a los medievalistas por ser "el léxico judeo-español, antiguo y actual a un tiempo, preciosa supervivencia donde perduran multitud de palabras y significados propios del español medieval" ${ }^{34}$.

[35a] Nehama, Joseph: Dictionnaire du judéo-espagnol, Madrid, CSIC, 1977.

[35b] Crews, Cynthia M.: «Textos judeo-españoles de Salónica y Sarajevo con comentarios lingüísticos y glosario», Estudios Sefardies, 2 (1979), pp. 91-258.

Recientemente se ha publicado un número especial de la revista Sephardica que recoge los trabajos presentados al Simposio Internacional celebrado en Hamburgo en 2008: Busse, Winfried y Studemund-HaLÉvy, Michale: Lexicología y lexicografía judeoespañolas, Peter Lang, 2011.

[35c] Por su parte, (A Coruña, Universidade, 2010) CAmpos Souto, Mar ha editado Las "Papeletas de voces castellanas" de Luis Usoz y Rí, autor que toma de la Biblia de Ferrara muchos arcaísmos ${ }^{35}$.

[36] De igual forma, se puede consultar con sumo aprovechamiento el Glosario de voces aljamiado-moriscas, preparado por GALMÉs de Fuentes, Álvaro, SÁnchez Álvarez, Mercedes, Vespertino Rodríguez, Antonio y Villaverde Amieva, Juan Carlos, Oviedo, Biblioteca Árabo-Románica, 1994.

\subsection{ESTUDIOS LÉXICOS}

\subsubsection{SOBRE CAMPOS ESPECÍFICOS DEL LÉXICO MEDIEVAL}

Conviene no olvidar la existencia de estudios sobre parcelas temáticas concretas del vocabulario de la época, pues, gracias a su enfoque temático, pueden usarse para aclarar el significado de voces especializadas de uso restringido, pero también en la búsqueda onomasiológica, es decir, para ir del concepto a la palabra (v. infra), como bien señala SECo, Manuel, en "El relevo de las palabras": "el léxico es, de los tres componentes de la lengua, el que más directamente refleja las realidades extralingüís-

\footnotetext{
${ }^{34}$ RAE, Diccionario histórico de la lengua española, Madrid, Imprenta Aguirre, 1972, fascículo preliminar, p. IX.

35 El trabajo de Usoz también interesa a los medievalistas por la definición de palabras (y de unidades léxicas complejas) sacadas de los pergaminos medievales custodiados en el archivo municipal coruñés y de otras obras del período medieval; así define, por ejemplo, encerrar razones: 'frase del siglo XIV, por acabar de decir sus razones, epilogar o concluir su discurso; no tener más que decir. Voz o frase forense de aquel tiempo, como se ve en varios instrumentos judiciales' (ed. cit., s.v. “razón”).
} 
ticas" (en CAmpos Souto, Mar et al. (eds.), El nuevo léxico, A Coruña, Universidade, 2007, pp. 9-25). Puesto que en la actualidad es relativamente fácil localizar en Internet las referencias bibliográficas correspondientes, apuntamos solo algunos ejemplos representativos:

[37a] Alfau de Solalinde, Jesusa: Nomenclatura de los tejidos españoles del siglo XIII, Madrid, Imprenta Aguirre, BRAE, 1969.

[37b] Carrasco Cantos, Pilar: "El léxico de los oficios municipales en las ordenanzas andaluzas", en Girón Alconchel, José Luis et al. (eds.), Estudios ofrecidos al profesor José Jesús de Bustos Tovar, Madrid, Universidad Complutense, 2003, vol. I, pp. 497-510.

[37c] Carvalho Homem, Armando y Beceiro Pita, Isabel: "Rey y «Totalidad Nacional» en la obra de Don Duarte: en torno a los conceptoss de prudencia y consejo", en Hispania: Revista española de historia, 67/227 (2007), pp. 929-944.

[37d] Díez de Revenga Torres, Pilar: "Algunos oficios y léxico especializado en la Edad Media", en Girón Alconchel, José Luis et al. (eds.), Estudios ofrecidos al profesor José Jesús de Bustos Tovar, Madrid, Universidad Complutense, 2003, vol. I, pp. 529-544.

[37e] Líbano Zumalacárregui, Ángeles: "El léxico de los recursos naturales en el romance medieval: materiales para su estudio", en CAMPOS Souto, Mar, et al. (coords.), Historia del léxico español, Universidad de la Coruña, 2007, pp. 81-96.

[37f] Márquez Villegas, Luis: Un léxico de la artesanía granadina, Granada, 1961.

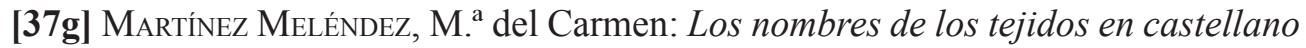
medieval, Granada, Universidad, 1989.

[37h] Montero Cartelle, Enrique: "La sexualidad medieval en sus manifestaciones lingüísticas: pecado, delito y algo más", en Clío \& Crimen, 7 (2010), pp. 41-58.

[37i] Moreta Velayos, Salustiano: "El caballero en los poemas épicos castellanos del siglo XIII: Datos para un estudio del léxico y de la ideología de la clase feudal", en Studia historica. Historia medieval, 1 (1983), pp. 5-2836.

[37j] Sesma Muñoz, José Ángel y Líbano ZumalacárRegui, Ángeles: Léxico del comercio medieval en Aragón, Zaragoza, Institución Fernándo el Católico, 1982.

36 En la ya citada página Lexical Studies of Medieval Spanish Texts (<http://www.hispanicseminary. org/ lexical-es.htm $>$ ) dirigida por Dworkin, Steven y GAGO-Jover, Francisco, figuran muchos otros títulos agrupados en: obras generales, de los ss. XI y XII, del s. XIII, del s. XIV y del s. XV, lo cual permite buscar con toda rapidez y comodidad. Respecto al léxico específico de los romanceamientos bíblicos medievales, puede consultarse el enlace a la bibliografía presente en $<$ http://www.bibliamedieval.es $>$, bajo la dirección de EnRiQue Arias, Andrés. 


\subsubsection{SOBRE VOCES CONCRETAS INTERESANTES PARA HISTORIADORES}

Suelen aparecer en revistas especializadas, en artículos cuyo título reproduce el término estudiado, por lo que se recomienda buscar ese término (y sus equivalentes en varias lenguas) en las bases de datos bibliográficos, sobre todo en el MLA (Modern Language Association, International Bibliography).

[38a] García Casar, Fuencisla: "El vocablo converso: su uso y su abuso", Convivencia de culturas y sociedades mediterráneas, Navarra, Universidad Pública, 2004, pp. 157-175.

[38b] Maíllo Salgado, Felipe: “Jinete, jineta y sus derivados. Contribución al estudio del medievo español y al de su léxico", Studia Philologica Salmanticensia, 6 (1982), pp. 105-117.

[38c] Maíllo Salgado, Felipe: "Diacronía y sentido del término elche", Miscelánea de Estudios Árabes y Hebraicos, XXXI (1982), pp. 79-98.

[38d] Maíllo SAlgado, Felipe: "Precisiones para una historia de un grupo étnicoreligioso norteafricano: los farfanes", Al-Qantara, IV (1983), pp. 265-281.

[38e] Maíllo Salgado, Felipe: "Contenido, uso e historia del término enaciado", Cahiers de Linguistique Hispanique Médiéval, 8 (1983), pp. 157-164.

[38f] Maíllo Salgado, Felipe: "Notas sobre el contenido y referente de la palabra almogataz", Studia Zamorensia, 5 (1984), pp. 471-480.

[38g] Maíllo Salgado, Felipe: "Estudio del sentido y referente de muqaddam > muqeddem > (al)mocadén", Studia Zamorensia Historica, VI (1985), pp. 363-373.

[38h] Maíllo Salgado, Felipe: "Función y cometido de los adalides a la luz de textos árabes y romances. Contribución al estudio del medievo español y al de su léxico", en Carrete, Carlos (ed.), Actas del III Congreso Internacional "Encuentro de las Tres Culturas» (Toledo, 1984), Toledo, Ayuntamiento, 1988, pp. 109-130.

[38i] Maíllo SALGado, Felipe: "Acerca del significado y referente del término mudéjar", en CARrete, Carlos (ed.), Actas del IV Congreso Internacional "Encuentro de las Tres Culturas» (Toledo, 1985), Toledo, Ayuntamiento de Toledo/Universidad de Tel-Aviv, 1988, pp. 103-112.

[38j] Maíllo Salgado, Felipe: "Acerca del significado y referente del término exea", en Borrego, Julio et al. (eds.), Philologica I. Homenaje a D. Antonio Llorente, Salamanca, Universidad, 1989, pp. 295-301.

[38k] Maíllo Salgado, Felipe: "El arabismo algoz (<al-guzz). Contenido y uso", en Historia. Instituciones. Documentos (Homenaje al profesor D. José Martínez Gijón), 26 (1999), pp. 319-328.

[381] Oliver Pérez, Dolores: "Una nueva interpretación de árabe, muladí y mawla como voces representativas de grupos sociales", en Lorenzo SAnz, Eufemio (ed.), Proyección histórica de España en sus tres culturas, Castilla y León, América y el Mediterráneo, vol. 3, 1993, pp. 143-156. 
[38m] Oliver PÉrez, Dolores: "Sarraceno: su etimología e historia", Al-Qantara, 17/1 (1996), 99-130.

\subsubsection{SOBRE PALABRAS DE DETERMINAdO ORIGEN ETIMOLÓGICO}

En bastantes ocasiones, la forma de una palabra desconocida o su contexto de uso $\mathrm{u}$ otras consideraciones pueden permitirnos sospechar que se trata de una voz de un origen etimológico determinado. Si es este el caso, y no localizamos la palabra en los repertorios generales, conviene recurrir a los diccionarios de lusismos, galicismos, cultismos..., etc. Habría que mencionar muchísimos títulos y quizá este enfoque resulte demasiado "lingüístico" para historiadores, por lo que en el apartado siguiente apuntaremos algún ejemplo concreto al hablar de alguna búsqueda concreta y ahora nos limitaremos a remitir a:

[39] BAJo PÉREz, Elena, "Bibliografía para el estudio de la caracterización de las voces conforme a su procedencia etimológica", Moenia, 3 (1997), pp. 601-634. También en línea: <minerva.usc.es/bitstream/10347/5937/1/pg_603-636_moenia3.pdf>

\section{LA BÚSQUEDA LÉXICA}

Desentrañar el significado de los textos exige reconocer las unidades léxicas que los forman y averiguar su significado. Tiende a creerse que lo difícil es encontrar el significado de las voces desconocidas, pero a veces cuesta más delimitar correctamente las unidades léxicas, y no siempre es fácil advertir que una forma del todo extraña puede ser solo una variante más o menos previsible de una voz mucho más conocida o reconocible.

Aun a riesgo de incurrir en perogrulladas, debe tenerse presente en todo momento que, aparte de que hay diccionarios mejor o peor elaborados, existen diccionarios de muy diversos tipos: recurrir o no a unos o a otros, hacerlo antes o después, depende de varios factores, entre los que destaca el tipo de consulta, es decir, el tipo de problema que afrontemos. CADA TIPO DE CONSULTA PLANTEA DIFICULTADES ESPECÍFICAS. Las preguntas que podemos formularnos en cada caso son: ¿qué diccionarios hay que consultar?, ¿en qué orden?, ¿de qué forma?

ES MÁs, CADA CONSULTA CONCRETA DEBERÍA CONCEBIRSE CON UN ITINERARIO SINGULAR DE BÚSQUEDA. Esto se debe a la naturaleza particular de cada voz, pero también al lamentable hecho de que varios de los diccionarios fundamentales no han sido completados; nos referimos especialmente al Diccionario Histórico (DHLE) de la RAE y al Diccionario del español medieval (DEM), dirigido por Bodo Müller, de los que ya hemos tratado (v. supra [27] y [16a]). Es forzoso, aunque incómodo, tener siempre presente hasta dónde han llegado estos dos diccionarios e, incluso, contar siempre con la posibilidad de que el término que estamos buscando posea una variante sí documentada en lo ya registra- 
$\mathrm{do}^{37}$. En el caso de voces comenzadas por $a$ - (hasta apasanca) o por $b$ - (hasta bajoca), NO EXISTE EXCUSA ALGUNA que pueda justificar que se abandone una búsqueda sin haber consultado el DHLE, que, además, desde hace pocos meses se puede consultar con toda comodidad en línea (<www.rae.es $>$ ):

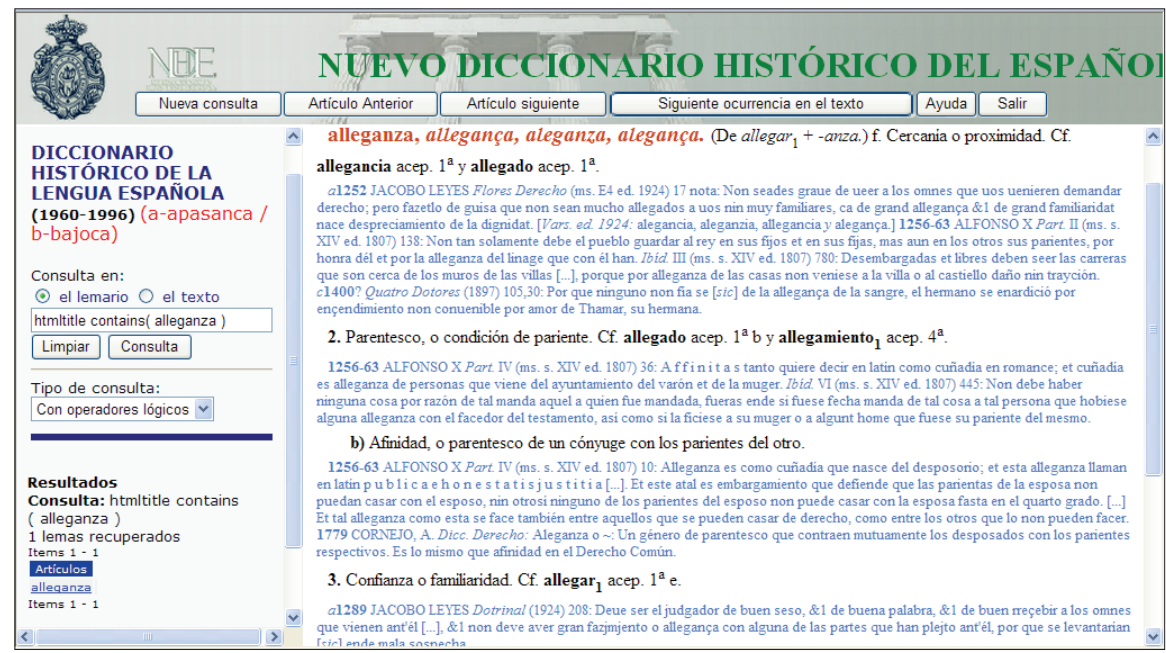

Es más, se pueden consultar palabras que empiecen por otras letras, no como lemas definidos sino como meras palabras localizadas en alguna parte del DHLE: por ejemplo, se puede ver que la voz picota aparece en cinco entradas, una de ellas alacitonar:

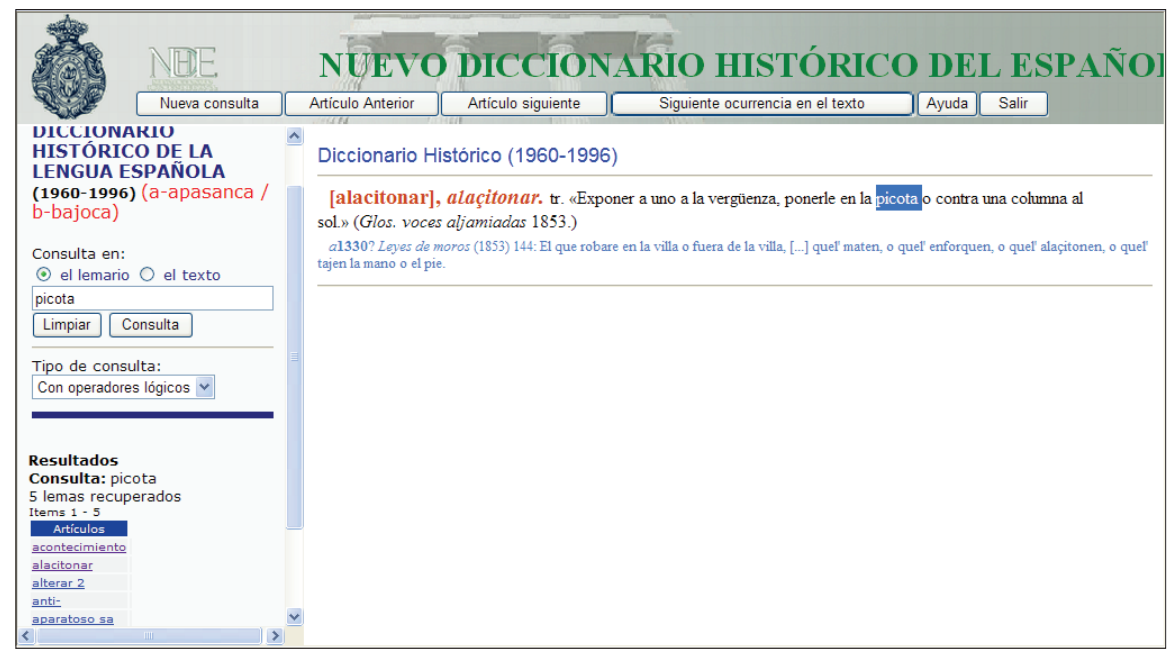

37 En el léxico medieval, las palabras comenzadas por $a$-suponen un tanto por ciento muy elevado del vocabulario total, debido, entre otros factores, al elevado contingente de arabismos y a la presencia de muchos derivados con $a$-, lo cual explica el considerable número de dobletes verbales, como recuerda MüLLER, Bodo: “Aspectos del léxico medieval”, en LüdtKe, Jens y Schmitt, Christian (eds.), Historia del léxico español. Enfoques y aplicaciones, Madrid/Frankfurt am Main, 2004, pp. 61-71. 
Tampoco se puede abandonar la búsqueda de una palabra que comience por "a" $\sin$ consultar el DEM (v. supra [16a]), que llega hasta almohatac.

$\mathrm{Y}$, a pesar de su planteamiento desfasado, casi de igual modo habría que censurar que en palabras que lleguen hasta cevilla, no se consulte el antiguo Diccionario Histórico (A-cevilla), disponible en línea a través de la página de la RAE y en DVD, en el NTLLE (v. supra [30]).

Hasta el momento, en español no había posibilidad de consultar fichas lexicográficas reunidas para llevar a cabo diccionarios: las fichas constituían una parte del trabajo lexicográfico que el usuario de un diccionario nunca llegaba a conocer directamente. En la actualidad, la situación ha cambiado de forma sustancial: ante la imposibilidad de llevar a su término (al menos en un período temporal relativamente breve) tanto el $D H L E$ como el $D E M$, se ha optado por digitalizar los ficheros y sacarlos en Internet. En el caso del $D E M$, todavía no se encuentran disponibles, aunque los nuevos responsables confían en no tardar mucho. En el caso de nuestro DHLE, ya se pueden consultar sus ficheros y también los ficheros generales de la RAE. Y esto constituye un festín y un filón para cualquier investigador, porque no existen restricciones: se pueden buscar palabras que comiencen por cualquier letra del alfabeto.

En el FICHERO GENERAL [40] abundan las fichas manuscritas y también las mecanografiadas con anotaciones y subrayados hechos a mano:

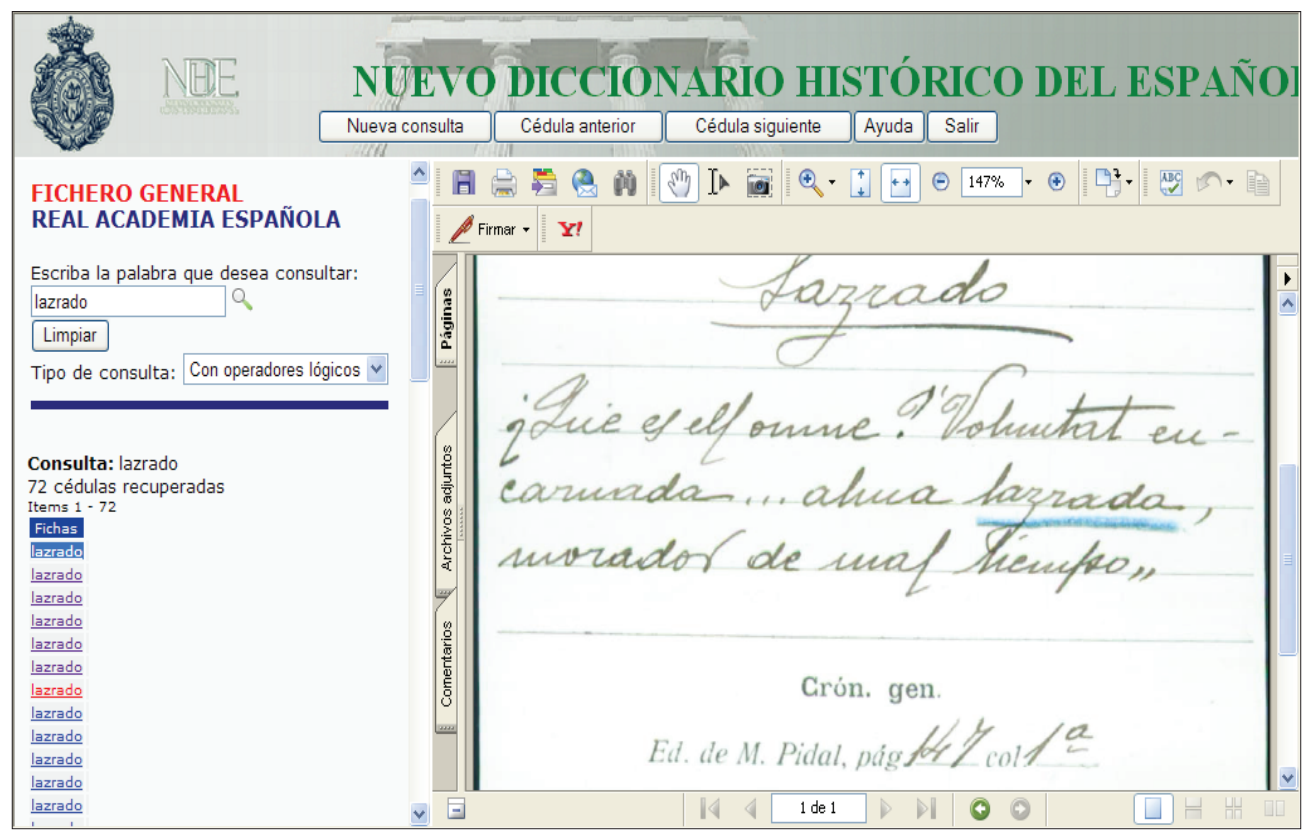




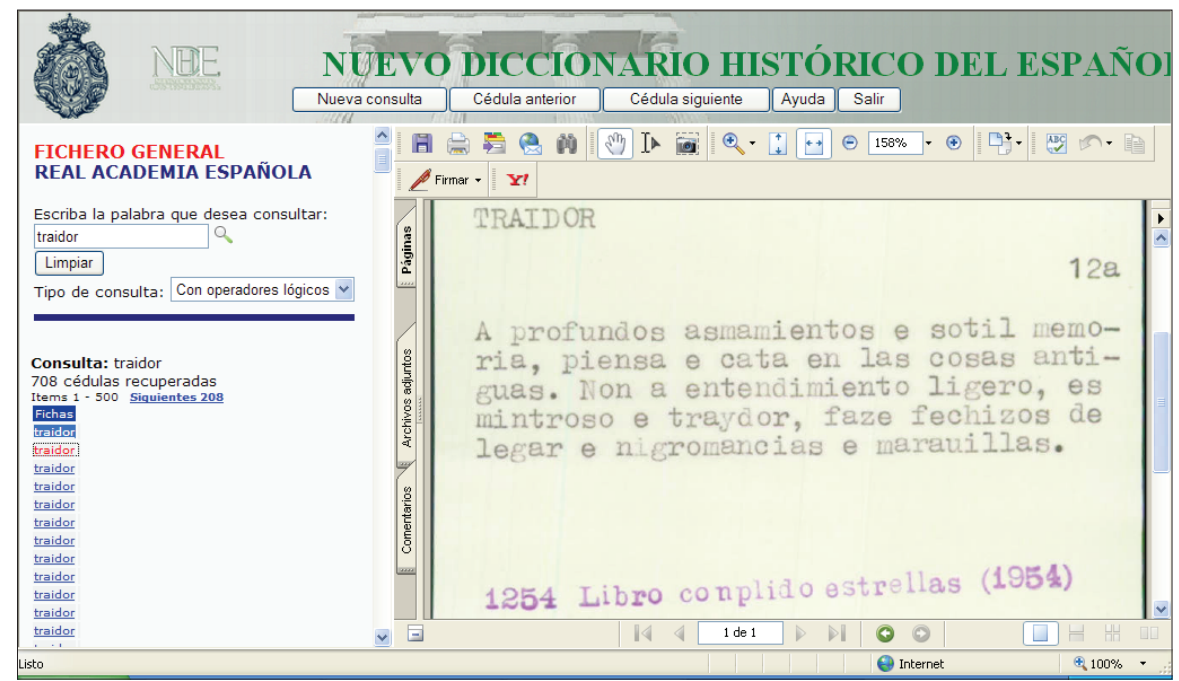

También se puede consultar el CoRPus del Nuevo Diccionario Histórico del Español [41], a través de páginas de concordancias. En el ejemplo reproducido infra, se ha preguntado por el lema «impiedad»y la respuesta incluye todas las variantes antiguas (jmpiedat, inpiedat, inpiadat, impiedat, inpiedad) y todas las formas flexivas de la palabra (singular y plural); también aparecerían diminutivos o aumentativos si los hubiera. A través de la ventana "subcorpus" puede limitarse la búsqueda por países, por autores, por títulos, por fechas, por temas, por posición dentro del texto, etc. Ciertamente, no es un diccionario histórico lo que se nos ofrece, porque del significado no se nos aclara nada, pero es una base de datos con lematización y, sin duda, se puede consultar con notable aprovechamiento.

\begin{tabular}{|l|l|l|l|l|l|}
\hline \hline & \\
\hline
\end{tabular}


Lamentablemente, la parte estadística no les servirá de mucho a los medievalistas, ni en la dispersión diatópica de las voces por los distintos países hispanohablantes ni en la dispersión diacrónica, pues no se discrimina cronológicamente dentro de la Edad Media: el primer bloque cronológico va desde el año 1064 hasta el año 1500.

Por último, a los medievalistas les conviene tener noticia del llamado Mapa de diccionarios [42]: aunque solo sirve para contrastar definiciones de los diccionarios académicos (todos muy posteriores al Medievo), puede resultar útil si se quieren revisar términos de definición polémica, cambios en la definición de arcaísmos, etc.:

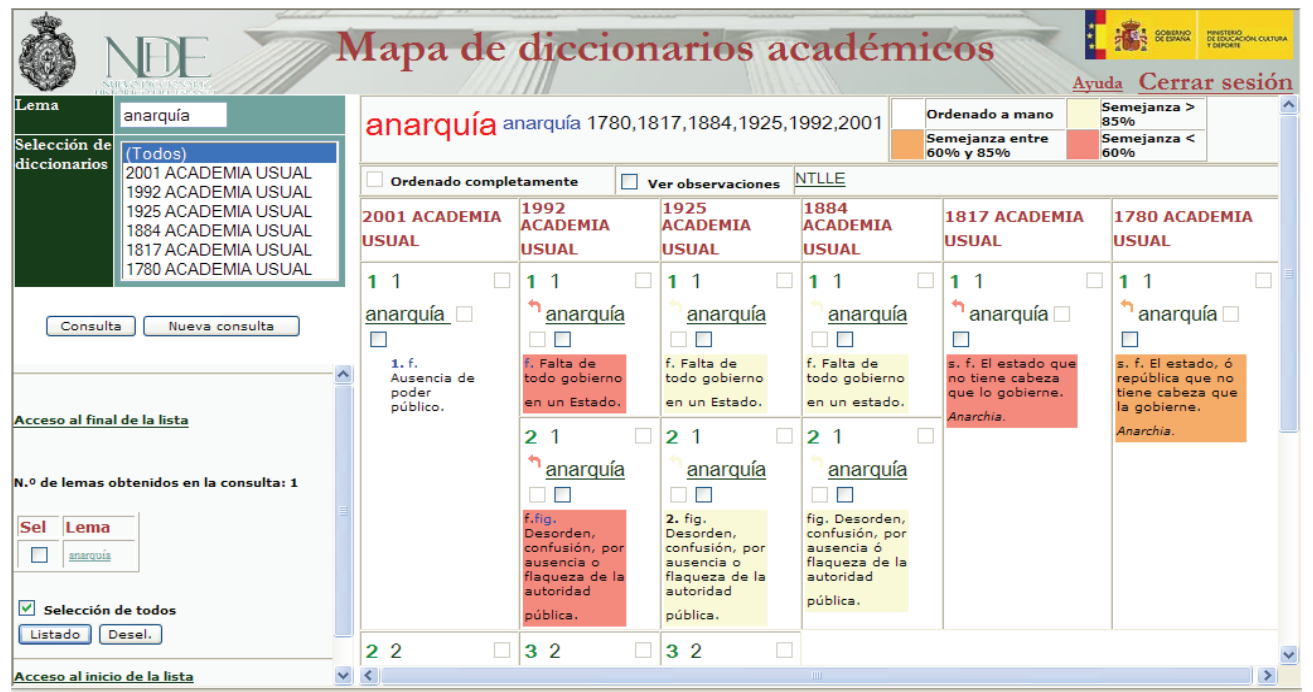

\subsection{BÚSQUEDA INVERSA (Y BÚSQUEDA A TRAVÉS DE FRAGMENTOS)}

Un texto poco legible, con rotos o partes deterioradas o emborronadas puede enfrentarnos al problema de tener que reconstruir alguna palabra ${ }^{38}$.

Si contamos con el comienzo de la palabra, podemos recurrir (para averiguar de qué palabra se trata) a cualquier repertorio léxico ordenado alfabéticamente, preferiblemen-

38 Nos referimos a situaciones en las que contamos con algo (alguna secuencia de letras) porque, si no queda nada o casi nada, solo podremos elucubrar jugando con el contexto (atendiendo, por ejemplo, a las combinaciones habituales de las palabras más cercanas al hueco). En el corpus de Davies (<www. corpusdelespanol.org $>$ ) podríamos intentarlo de las siguiente manera, si, por ejemplo, desconociéramos una palabra antepuesta o pospuesta a «escudero»: [escudero] * (en el siglo Xv) [Búsqueda de una palabra concreta seguida de cualquier otra, en un período temporal concreto] * [escudero] (en el siglo XIV) [Búsqueda de una palabra concreta precedida de cualquier otra, en un período temporal concreto]En una situación similar nos encontraremos cuando, de una palabra, solo dispongamos de un prefijo o de un sufijo, o todavía peor, solo de morfos flexivos. En estos casos, si gracias a los prefijos, sufijos o morfos flexivos, podemos deducir la clase de palabra (verbo, sustantivo, adjetivo, etc.), entonces estaremos en condiciones de recurrir a las palabras del contexto para intentar reconstruir. Por ejemplo: [j*] escudero (en el siglo XIII) [Búsqueda de una categoría gramatical (en este caso, adjetivo: $\left[\mathrm{j}^{*}\right]$, combinada con una palabra concreta y en un período temporal concreto.] escudero [ $\mathrm{v}^{*}$ ] (en cuatro siglos) [Búsqueda de una palabra concreta seguida de verbos, en cuatro siglos, con petición de señalar la diferencia siglo por siglo.] 
te, a un diccionario general, aunque, dependiendo de los textos, podría ser también a un glosario especializado, a un vocabulario de autor, etc. Si las letras iniciales presentan variantes gráficas (véase infra), habría que contar con ello y ramificar la búsqueda.

$\mathrm{Si}$, por el contrario, únicamente disponemos del final, habría que recurrir a los diccionarios inversos, denominados así porque, aunque también están ordenados alfabéticamente, van del final de cada palabra al principio. Estos diccionarios derivan de los antiguos diccionarios de rimas, pero han resultado muy útiles a la hora de recomponer folios incompletos partidos longitudinalmente o, simplemente, folios con agujeros o borrones. Para los medievalistas, una obra muy aprovechable en este sentido es el volumen once del NTLE (v. supra [31]), cuyas 327 páginas constituyen un índice inverso de todas las voces lematizadas en los diez volúmenes previos.

En la actualidad, numerosas obras lexicográficas en formato digital permiten buscar de forma inversa ${ }^{39}$.

[43] RAE, Diccionario de la lengua española, Madrid, Espasa, 2003, $22^{\mathrm{a}}$ ed., en CD.

[44] Moliner, María, Diccionario de uso del español, Madrid, Gredos, 2008, 3ª ed., en $\mathrm{CD}$.

Más centrados en el léxico actual -y, por tanto, de entrada menos útiles para medievalistas- contamos con el Gran diccionario de lengua española [45a], coordinado por MARTí, María Antonia, Barcelona, Larousse, 1996 y 2003, en CD, y Clave. Diccionario de uso del español actual [45b], dirigido por MALDONADO, Concepción, Madrid, SM, 2002, en CD, sobre la ed. de 1996. Este último se puede consultar también en línea $<\mathrm{http}$ //clave.librosvivos.net>

De todas formas, más cómodo y más efectivo cuando se trata de reconstruir voces de textos medievales es recurrir a los comodines en los corpus textuales ya citados (el CORDE y el Corpus del español):

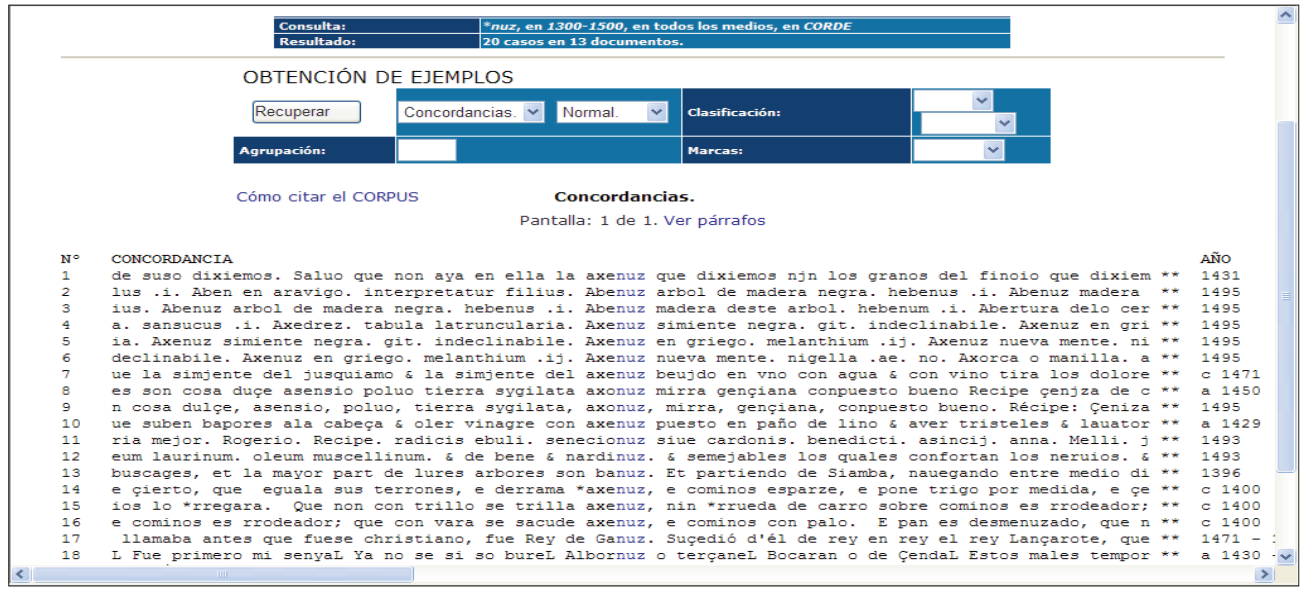

39 Véase Águila Escobar, Gonzalo: Los diccionarios electrónicos del español, Madrid, Arco/Libros, 2009, sobre todo, los subapartados dedicados a "Tipos de búsqueda" en el diccionario académico y en el Diccionario de Uso, de María Moliner. 


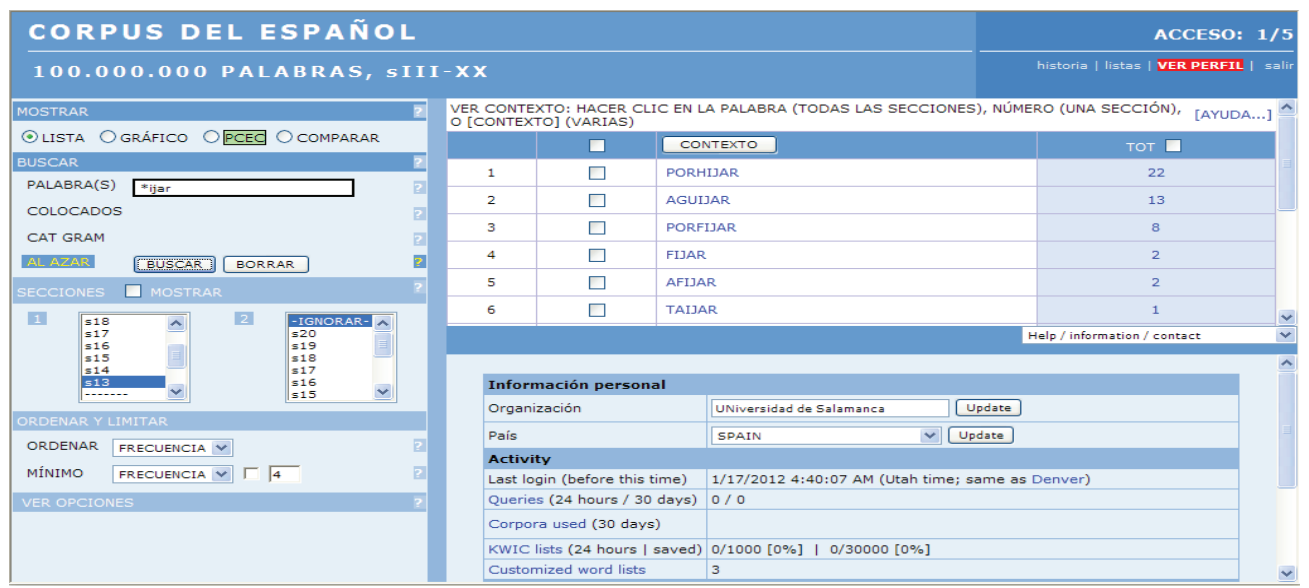

Gracias a los comodines, es posible incluso buscar palabras que contengan en su interior determinadas secuencias de letras, lo cual puede permitir localizar palabras de las que falte el principio y el final. Una búsqueda de este tipo está prevista en la edición digital -de sumo interés para medievalistas- del Glosario de la versión castellana de fray Vicente de Burgos del De Proprietatibus Rerum de B. Ánglico [en línea] <http://campus.usal.es/gedhytas $>$ (v. supra [25e]):

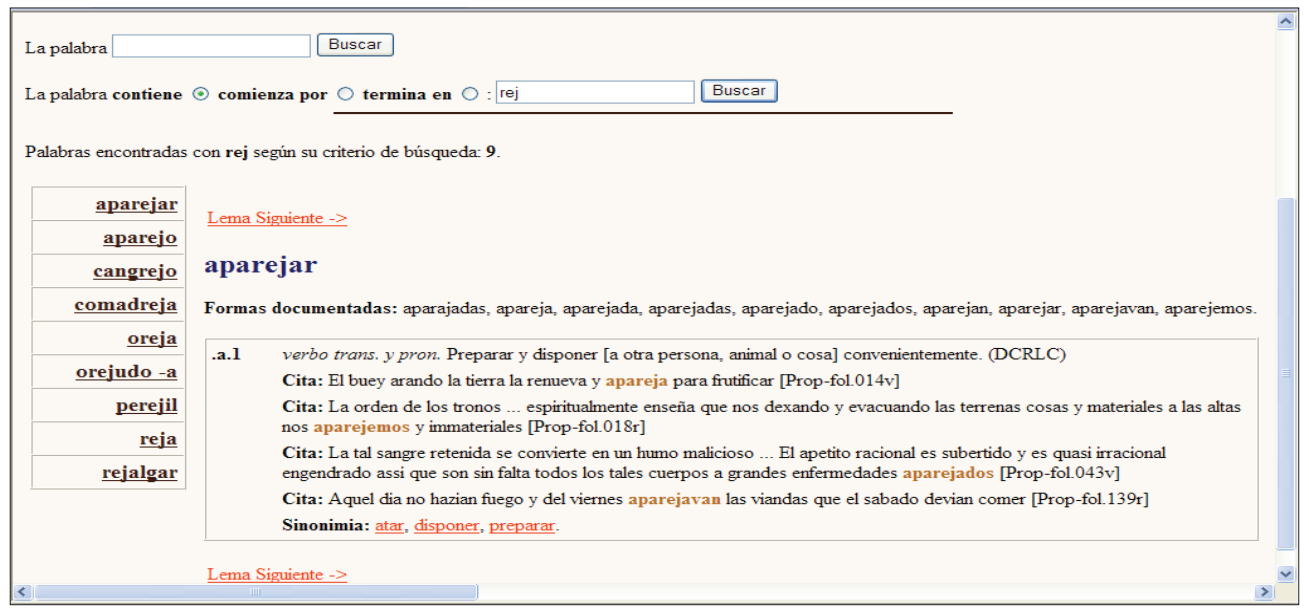

\subsection{BÚSQUEDA SEMASIOLÓGICA}

Por lo general, recurrimos a los diccionarios para buscar el significado de una palabra que no conocemos en absoluto o que conocemos, pero no en una acepción que encaje con el contexto en el que la hemos encontrado. Puesto que en la historia del léxico existen discontinuidades, para evitar las interpretaciones anacrónicas, hay que tener en cuenta que puede darse lo que Álvarez DE Miranda, Pedro (“cap. cit.”, p. 156) 
llama "la poligénesis temporal de préstamos (especialmente latinismos) y derivados (social, burgués o primaveral «nacieron» varias veces en español)".

\subsubsection{LOCALIZACIÓN DE LAS VARIANTES ${ }^{40}$}

En los textos medievales abundan las voces que se documentan solo una vez, pero, sobre todo, coexisten numerosas variantes gráficas, fonéticas y morfológicas, lo cual complica mucho la búsqueda. Las variantes morfológicas (relacionadas o no con la falta de fijación gramatical) pueden resultar hasta cierto punto imprevisibles $\mathrm{y}$, por esa razón, no las vamos a tratar aquí; por el contrario, las variables gráficas y fonéticas son en muchos casos esperables. En los diccionarios y glosarios (no así en las bases de datos, por lo general), las voces aparecen en su forma gráfica más habitual, pero puede suceder que no sepamos cuál es la más habitual y puede suceder también que no se faciliten remisiones desde las variantes menos frecuentes a las más frecuentes; por eso mismo, antes de buscar una voz en cualquier obra lexicográfica, conviene elaborar una lista con sus posibles variantes gráficas y fonéticas.

Para buscar variantes ya documentadas y constatadas, hay que recurrir básicamente al DH, al DEM, al LHP, al DCECH, al NTLE, y al Corpus del Nuevo Diccionario Histórico, en la ventana de Estadística (v. supra, respectivamente, [27], [16a], [20], [28], [31] y [40]). Algunas de estas obras ofrecen, además, información sobre la cronología, distribución geográfica y estimación social de las variantes. Sin olvidar que, tal como se asegura en su "Presentación", el Diccionario de la prosa castellana del rey Alfonso X (v. supra [13e]) "incorpora una novedad para los registros lexicográficos, la inclusión exhaustiva de las formas atestiguadas, recogiendo todas las variantes, tanto grafémicas como morfológicas" ${ }^{\prime 4}$.

${ }^{40}$ La presencia de variantes no siempre debe considerarse muestra de vacilación $-\mathrm{y}$ mucho menos de impericia-, pues con frecuencia es un rasgo de estilo: véase MorreALE, Margherita, "Transcendencia de la variatio para el estudio de la grafía, fonética, morfología y sintaxis de un texto medieval, ejemplificada en el Ms Esc. I.I.6", Annali della Facoltà di Lettere e Filosofia dell'Università di Padova, II (1977), pp. $249-261$.

$41 \mathrm{Si}$ estas obras no nos proporcionan variantes para alguna búsqueda concreta, tendremos que discurrirlas por nuestra cuenta. Podemos tener presente las siguientes recomendaciones: 1. En una palabra que conozcamos con "v", al menos hay que tener en cuenta que la "u" puede aparecer con valor consonántico, y que la "b" puede aparecer en lugar de la "v". Exactamente igual ocurre cuando conocemos la voz con "b": hay que buscarla también con "v" y con "u", ejs. de (1) y (2). 2. Una palabra con "y" puede tener variantes con "i" y con " $j$ ". Y una palabra con "j" básicamente puede tener variantes con "i”, con "g", con " $x$ ", ejs. de (3), (4) y (5). 3. La "l" y la "r" pueden alternar en posición implosiva y en grupos de muta cum liquida, ejs. de (6). 4. Son frecuentes los casos de vacilación en el timbre de las vocales átonas, ejs. de (7). 5. En lugar de "ñ" puede aparecer "nn", ejs. de (8). 6. Algunos grupos consonánticos pueden no haberse resuelto todavía, pueden haberse reducido, pueden haberse reinterpretado, ejs. de (9). 7. Pueden darse casos de prótesis, epéntesis o paragoge, ejs. de (10). 8. Pueden darse casos de aféresis, síncopa o apócope, ejs. de (11). (1) almogávar, almogáuar, almogábar (2) babera, bavera, vavera, vabera, bauera, uavera, uauera (3) yantar, intar, jantar (4) ojo, oio; pajar, paiar; majestad, maiestad, magestad enajenar, enagenar; jengibre, gengibre (5) dejar, dexar; enjambre, enxambre; jarabe, xarabe (6) mármol, mármor; marfil, almafil, amarfil, armafil, almafy (7) dibujar, debujar; ministro, menistro (8) daño, danno (9) deuda, debda; indigno, indino, indimno; lector, letor; (10) mellizo, melliço, embellizo; omne, ombre; alfoz, alfoce (11) amor, mor; dolerá, dolrá; nueve, nuef. En voces de uso muy corriente, pueden aparecer muchas más variantes, pero no suelen plantear problemas de identificación (piénsese en mujer o iglesia, por ejemplo). Sin embargo, cuando un término es un extranjerismo, la posibilidad de variación gráfica y fonética es mayor, puesto que, en la acomodación al español, cada voz 


\subsubsection{BÚSQUEDA DEL SIGNIFICADO}

Caso 1: La palabra aparece en una obra o autor que disponen de vocabularios o glosarios específicos.

Ejemplo: La voz aparece en una obra de Alfonso x el Sabio. Entonces, se consultan primero las obras lexicográficas específicas sobre este autor: [13a], [13b], [13c], [13d] y [13e]. Después, si es necesario, se sigue con el itinerario normal: [30] y [31] o, en su caso, [27] y [16a].

Caso 2: Por razones contextuales o de otro tipo, se deduce que una palabra tiene que ver con la vida campesina (todo lo relativo a las faenas agrícolas, el ganado, las tareas domésticas, los trabajos artesanales rurales, las celebraciones, los juegos, etc.).

Ejemplo: Podría tratarse del nombre de algo usado en algún tipo de festividad. La voz en cuestión empieza por j-, y en el DHLE [27] y en el DEM [16a] se comprueba que no existen variantes de esta voz que comiencen por $a$-. No aparece en ninguno de los dos tesoros ([30] y [31]). Tampoco en el corpus del $N D H$ [41], ni en el fichero de la RAE [40], etc. En ese caso, el paso siguiente será recurrir a los diccionarios dialectales: de [33a] a [33aj]. Si se puede concretar la zona geográfica o el área lingüística, se podrá precisar más: por ejemplo, para el ámbito del leonés, convendría consultar el muy exhaustivo Léxico del leonés actual [33s]. También se puede intentar una búsqueda onomasiológica (v. infra el apartado $3 \mathrm{~d}$ ), puesto que algunas de estas obras ofrecen un índice temático o una ordenación por temas; así ocurre con el Diccionario del castellano tradicional [33p] o con Hablares: el mundo rural y sus aportaciones al léxico castellano [33ab]. Igualmente, pueden ser útiles los atlas lingüísticos, especialmente, el [34g], que contiene los índices léxicos de todos los publicados hasta 1987, y el ALCCMAN [34c], consultable en red.

Caso 3: Por razones contextuales o de otro tipo, se sospecha que una palabra puede pertenecer a un campo restringido del vocabulario.

Ejemplo 1: Podría tratarse del nombre de un tejido. No se puede buscar en el DHLE [27], ni en el $D E M$ [16a], porque no empieza por $a$ - (ni por $b$-bajoca), ni posee variantes con $a$-. En ese caso, se busca primero en los dos tesoros [30] y [31], por si acaso está lematizado con esa forma o podemos llegar a ella por aproximación. Si no es así, buscamos en el LHP [20], en el corpus del $N D H$ [41], en el fichero de la RAE [40], etc. para ver si es una variante poco corriente de una palabra lematizada bajo otra forma. Si no se localiza, se pueden consultar las obras especializadas correspondientes:

sigue su propio ritmo y son muy frecuentes las ultracorrecciones, las etimologías populares y los cruces con voces similares: (12a) babor, ababor, bavor, vavor, bavord, babord (del neerlandés bakboord, probablemente a través del francés babord. DH: s.v. babor) (12b) bachiller, bacheller, bagiler, bachaller, vachiller, bachiler (del francés bachelier. DH: s.v. bachiller, ra) (12c) ajedrez, agedrez, ajedrés, ajadrez; axedrez, axedrés, axedrex, axedreç, axederez, axadrez, axadrés, axedez; acedrej, açedrej, acedrex, açedrex, acedreyx; açedex, acedrix; aljedrez, algedrez, aljedrés, alxedrez; axidriche, arcidriche, arçidriche, arcidrich (del árabe. DH: s.v. ajedrez). 
[21a]: Vocabulario del comercio medieval

[37a]: Nomenclatura de los tejidos españoles del siglo XIII

[37f]: Un léxico de la artesanía granadina

[37g]: Los nombres de los tejidos en castellano medieval

[37j]: Léxico del comercio medieval en Aragón

[24]: DICTER, en el apartado correspondiente a sastrería y tejidos

Ejemplo 2: Podría tratarse de un término relacionado con la medicina, la farmacopea... y, al igual que en el ejemplo 1, las obras generales no sirven de ayuda. En ese caso, se recurre a las obras propias de ese ámbito:

[22] Diccionario general de los textos médicos antiguos

[23a] y [23b] Dioscórides

Caso 4: Una palabra, de la que se ignora todo, parece un préstamo de un origen etimológico determinado.

Ejemplo: La voz parece un arabismo. Si empieza por $a$ - se busca en el DHLE [27] y en el DEM [16a] (solo hasta apasanca y hasta almohatac, respectivamente); si empezara por $b$ - hasta bajoca, igualmente se buscaría en el DHLE [27]. De no ser así, se comprueba que no tenga una variante que empiece por $a$ - (circunstancia frecuente en el léxico medieval). En caso contrario, se busca a continuación en los dos tesoros [30] y [31]. Si no se localiza, se intenta en el corpus del Nuevo Diccionario Histórico [41] a ver si aparece de alguna forma, incluso, como variante de otra voz más conocida. Si no es así, se va a [39] y se indaga en los repertorios clásicos de arabismos. Para redondear la búsqueda, se consulta la obra de conjunto más reciente: CoRRIENTE, Federico, Diccionario de arabismos y voces afines en iberorromance, Madrid, Gredos, 2003, $2^{\mathrm{a}}$ ed.

\subsection{BÚSQUEDA DE NOMBRES PROPIOS}

Ciertamente, no se pueden consultar los diccionarios antiguos como si fueran diccionarios enciclopédicos fiables o enciclopedias modernas con conocimientos actualizados, pero, sin duda, se perderá mucha información cultural y semiológica si se prescinde de las noticias sobre personajes, sucesos y lugares que facilitan las obras antiguas. En este sentido, el NTLE (v. supra [31]) no permite un aprovechamiento integral de las obras que lo constituyen: elimina los lemas que son nombres propios, así como buena parte de la información enciclopédica presente en las entradas, por lo general, también vinculada con la onomástica. Por el contrario, el NTLLE (v. supra [30]), al limitarse a reproducir las páginas de las obras, no elimina nada y, por lo tanto, facilita el acceso a toda la información, con independencia de que sea lingüística o enciclopédica: se pueden buscar nombres propios de todo tipo: Eva, Etiopía, Atlántico, Bucéfalo, Tizona...

En el caso de los diccionarios antiguos no recogidos en el NTLLE, habría que consultar directamente las obras más destacadas en cuanto a información enciclopédica o, si es posible, índices onomásticos de sus materiales.

Para el Universal Vocabulario (v. supra [7a]), obra de gran riqueza enciclopédica, pero de muy difícil consulta, algo puede ayudar el Registro de voces españolas internas (v. supra [7b]), pero poco, porque, como se aclara en las Advertencias Preliminares (p. 
VI), se han omitido casi todos los nombres propios y gentilicios, con la excepción de los "que se relacionan con España", afirmación poco clara, pues entre los conservados se hallan España o gallego, pero también Alamania, Anglaterra e, incluso, Armenia, además de Dios, Sathanas y otros semejantes.

También el Vocabulario eclesiástico (v. supra [9]) brinda abundante información enciclopédica y su consulta, a pesar de estar lematizado en latín, no es demasiado complicada.

Para la Recopilación [1593], extensa obra de DIEGO DE GUADIX, existe un detallado «Índice onomástico», en la edición preparada por BAJO PÉREZ, Elena, y MAíllo SALGADO, Felipe (Gijón, TREA, 2005, pp. 1085-1122). Comprende topónimos propiamente dichos, orónimos, hidrónimos, anemónimos y voces relacionadas, antropónimos y teónimos ${ }^{42}$.

También se ofrece un apartado de «Nombres propios», en el Glosario de voces aljamiado-moriscas (v. supra [36]), pp. 623-732. Recoge los antropónimos, topónimos, teónimos, títulos de obras, etc., de origen árabe o romance, localizados en las obras aljamiadas.

\subsection{BÚSQUEDA ONOMASIOLÓGICA}

Aunque es más común buscar en los diccionarios un significante para averiguar su significado, también es posible intentar ir de un significado o concepto a los significantes correspondientes. ¿Cuándo o para qué se plantea una consulta de este tipo?

Caso 1: Se trata de traer a la memoria un término momentáneamente olvidado, pero cuya existencia se conoce con certeza.

Ejemplo: Adjetivos antiguos para expresar que alguien posee suerte o fortuna.

Caso 2: Se trata de averiguar cómo se llama algo cuyo nombre se ignora, pero que, por lógica, debe de existir.

Ejemplo: Nombres de las partes de una lanza.

Caso 3: Se ignora si existe o no una palabra para designar un significado o un conjunto de rasgos semánticos.

Ejemplo: ¿Existe algún adjetivo que indique -en una sola palabra- que alguien es 'ignorante, mezquino y malintencionado'?

Caso 4: Se encuentra una palabra poco legible, pero perteneciente a un ámbito del vocabulario más o menos deducible por el contexto.

Ejemplo: Parece el nombre de un color.

En cualquier caso, solo hay dos diccionarios generales que, además de poder ser consultados onomasiológicamente, registran numerosos arcaísmos y voces anticuadas: [46] el Diccionario ideológico de la lengua española, de CASARES, Julio y el Diccio-

${ }^{42}$ Ni la Recopilación de Guadix, ni el Tesoro de Covarrubias reflejan ya el mundo medieval, pero aportan muchísima información aprovechable para los medievalistas. Del Tesoro existe una versión ilustrada en DVD, que comprende también el Suplemento y permite búsquedas rápidas (Arellano, Ignacio y Zafra, Rafael (eds.), Madrid, Iberoamericana/Vervuert, 2006). 
nario de uso, de Moliner, María (v. supra [44], aunque los medievalistas quizá puedan usar con igual o mayor comodidad la edición de 1966 en alguna de sus numerosas reimpresiones, porque en ella los términos desusados o poco usados aparecen en una letra más pequeña). El sistema de búsqueda onomasiológica es parecido en ambos: en la parte "normal" o semasiológica del diccionario, se busca una palabra relacionada con la consulta: en los ejemplos anteriores, serían, respectivamente, suerte y fortuna; lanza; ignorancia, mezquindad y mala intención y, por último, color. En esas palabras debemos encontrar remisiones a listas (en el caso de Casares) y a catálogos (en el caso de Moliner). Consultados listas y catálogos, aparecerán términos relacionados semánticamente, cuyo significado habrá que ir aclarando (palabra por palabra) hasta llegar a lo que se busca (si es que existe).

Además, bastantes diccionarios dialectales y también los atlas lingüísticos permiten rastrear del concepto a la palabra (v. supra el Caso 2, del aptdo. 3.2.2).

También pueden consultarse índices temáticos en obras que los contengan; por ejemplo, se podría buscar en el correspondiente a la edición citada en el apartado 3.3 de la Recopilación de GUADIX, pp. 1123-1186.

\section{CONCLUSIÓN}

El repaso anterior demuestra que son muchas las obras lexicográficas que pueden facilitar las investigaciones de los medievalistas. Como hemos señalado, según el tipo de objetivo deseado, convendría orientar y diversificar la búsqueda léxica de un modo u otro. Saber de la existencia de todas las obras lexicográficas mencionadas e, incluso, familiarizarse con ellas, no supondría gran esfuerzo en comparación con las ventajas que podrían obtenerse de su manejo.

Ahora bien, admitiendo todo tipo de salvedades para casos concretos, se pueden reducir a cuatro las obras fundamentales que, en ningún caso, deberían dejarse sin consultar: por una parte, los dos tesoros, el NTLLE y el NTLE (v. supra [30] y [31]), puesto que, aunque son muy diferentes entre sí, ambos permiten buscar en muchos diccionarios a la vez; por otra parte, los fascículos del DHLE (ya disponibles en línea) y los veintiséis fascículos del DEM (v. supra, respectivamente, [27] y [16a]), porque, a pesar de ser ambas obras incompletas y definitivamente interrumpidas, ofrecen un registro exhaustivo y un estudio específico del léxico medieval.

Precisamente para salvar la inconclusión de las dos obras anteriores, se debe recurrir a los dos ficheros correspondientes: el corpus del $N D H$ (v. supra [40]), que ya se puede consultar en línea, y el del $D E M$, llamado $A D E M$ (v. supra [16c]), que esperamos que muy pronto se encuentre también disponible; mientras tanto habrá que conformarse con el DEMi (v. supra [16b])

Estos dos tesoros y estos dos diccionarios exhaustivos (y sus respectivos ficheros) ofrecen una base óptima desde la que abordar el estudio y la comprensión de los textos medievales. Constituyen lo mínimo que se debería consultar: a partir de ahí, recurriendo a las restantes obras lexicográficas y a los estudios léxicos, cualquier búsqueda se podría afinar y depurar casi indefinidamente. 